\title{
توظيف مقاصد الشريعة في أسلمة المعرفة القانونية
}

\section{عليان بوزيان}

\author{
الملخص \\ تمدف هذه الدراسة إلى استثمار نظرية المقاصد الشرعية لإدراك جوهر القانون، ومحاولة التقريب والمصالحة بين

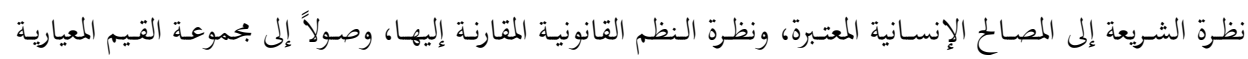 \\ الحاكمة، في صياغة تشريع معياري يتناسب مع المجتمعات الإسلامية. \\ وكشفت الدراسة عن الحاجـة إلى تأسيس علم مقاصد القـانون طلباً لمقاصد كلية قطعية يقُطَع بهـا الخـلاف، \\ فحيثما أسفر وجه الحق والعدل والمصلحة فثم مقصد القانون، ومن شأن ذلك فإن أسلمة المعرفة القانونية تمثل نقطة \\ الانعطاف في إعـادة بعث الجانب التشريعي من الشريعة، عن طريق تفعيل أدوات الفكر المقاصدي، واستثمارها في \\ تحديد فلسفة التشريع الوضعي.
}

الكلمات المفتاحية: مقاصد الشريعة، فلسفة القانون، روح القانون، المصلحة النفعية، أسلمة المعرفة.

\section{Employing purposes of Shariah in Islamization of legal knowledge}

\begin{abstract}
This study aims to apply the theory of Islamic legal purposes to grasp the essence of the civil law, and try to converge and reconcile perspective of Sharia on the legitimate interests of people, and the comparative legal systems, to develop governing normative values that are necessary to draft normative legislation, commensurate to Muslim societies.

The study revealed the need to establish a discipline of the purposes of the civil law applied for the universal purposes that settle disagreement. Where truth, justice and interest are emerged the civil law will be there. Islamization of legal knowledge represents a turning point in reviving the legislative side of Islamic law, by using the tools of maqasid thought, to determine the philosophy of civil legislation
\end{abstract}

Key words: Purposes of Shariah (maqsid), philosophy of law, spirit of Law, pragmatic interest, Islamization of knowledge.

$$
\begin{aligned}
& \text { *دكتوراه في الشريعة والقـانون، أستاذ محاضر قسـم"أ" - كلية الحقوق والعلوم السياسية جامعة ابن خلدون تيارت- } \\
& \text { الجزائر. البريد الإلكتروين: gmail.com }
\end{aligned}
$$

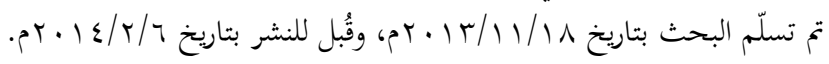




\section{مقدمة:}

الإسلام شريعة معيارية مقاصدية بامتياز، تراعي في أحكامها حفظ المصالح الحقيقية للإنسانية، وفي المقابل يسعى فلاسفة القـانون إلى إثبات أن القـانون علم معيـاري غـائي

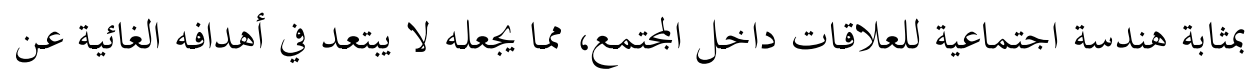

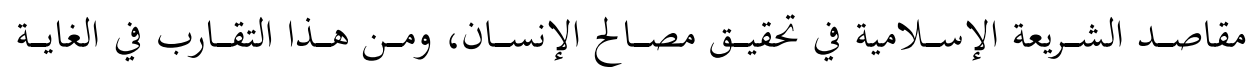

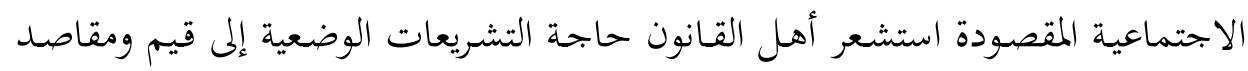

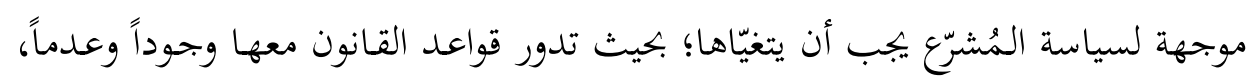
فاستحدثوا علم فلسفة القانون، وابتهت قلة منهم إلى استثمار نظرية المقاصد الشرعية في

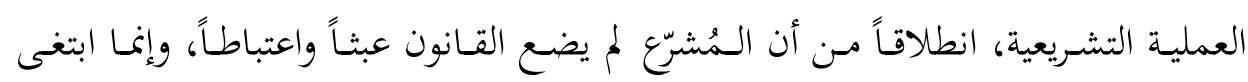

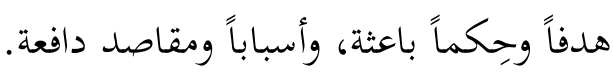

ومع ذلك الاستشعار بأهمية ربط القانون بروحه ومقاصده في الفهم والتطبيق، فإن

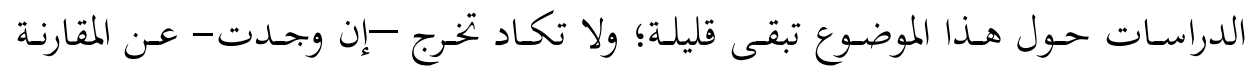

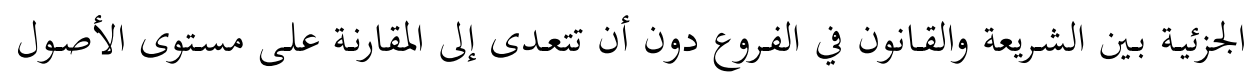

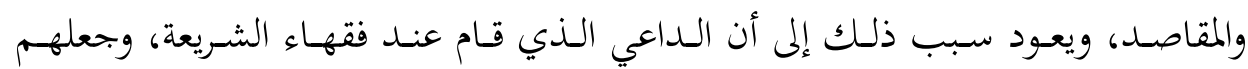

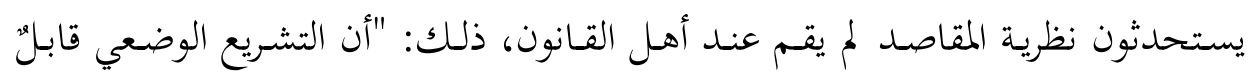

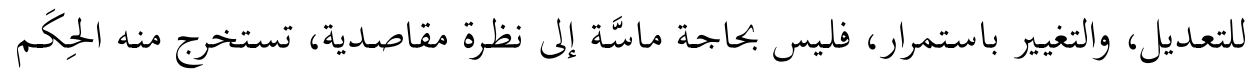

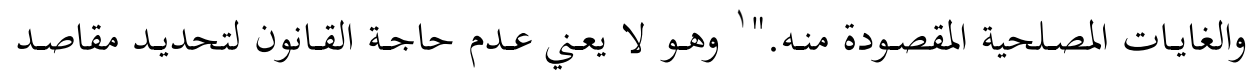
المُشرّع، ومعرفة روح التشريع. وبهذا تتحدد أهداف دراسة هذا الموضوع في استثمار نظرية المقاصد الشرعية لإدراك جوهر القـانون، حتى تكون مقاصد المكلفين المخاطبين بـالنص القـانوني في حالة انطباق

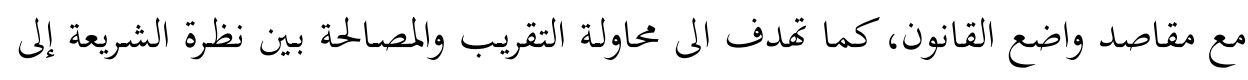

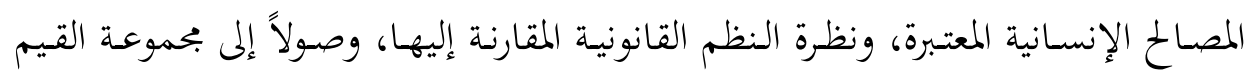
المعيارية الحاكمة، في صياغة تشريع معياري يتناسب مع المحتمعات الإسلامية.

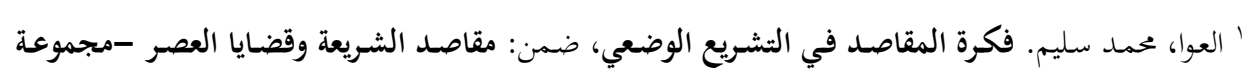

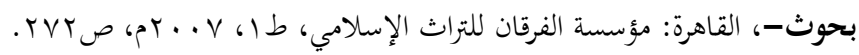




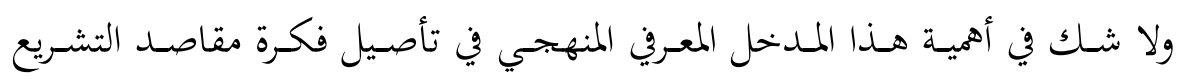

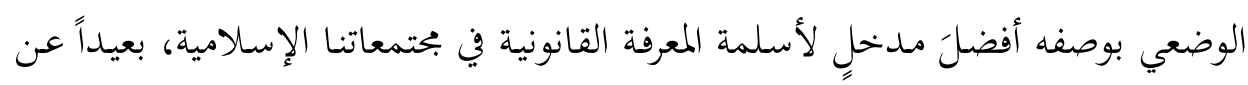

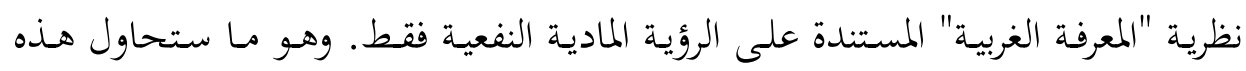

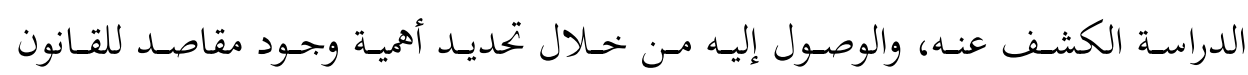

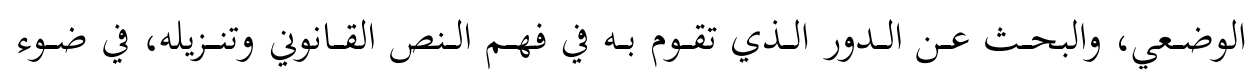
استثمار نظرية المقاصد الشرعية.

\section{أولاً: فلسفة القانون في ضوء مقاصد الشريعة}

من أهم ما يميز بجتمعاً ما من غيره طبيعة منظومته القانونية وآلياتما في التشريع، لما

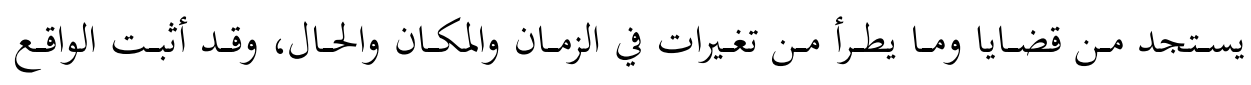

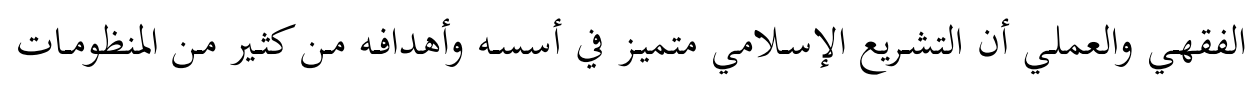

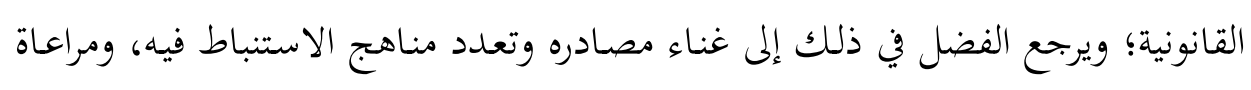

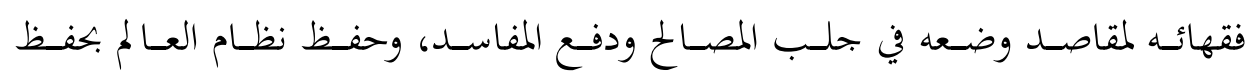

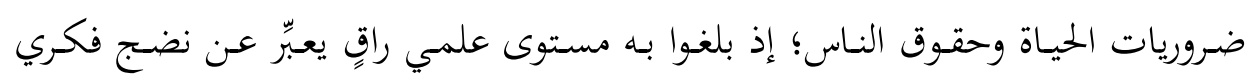

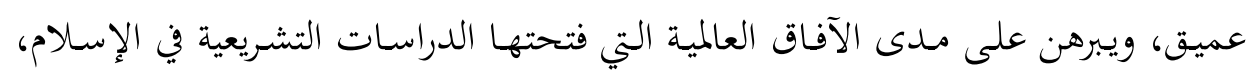

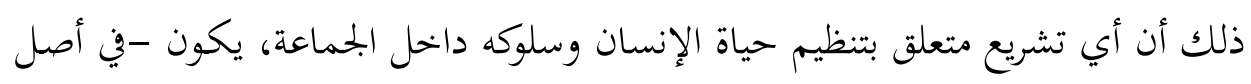

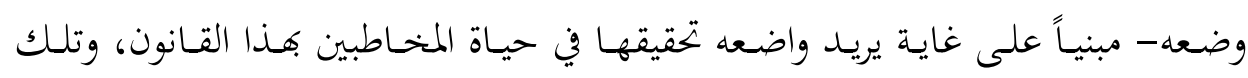

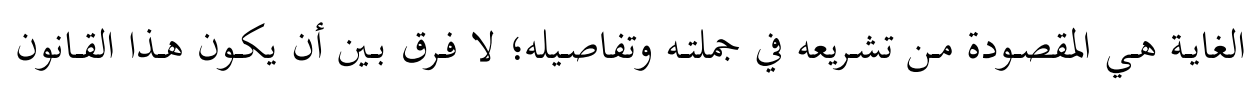

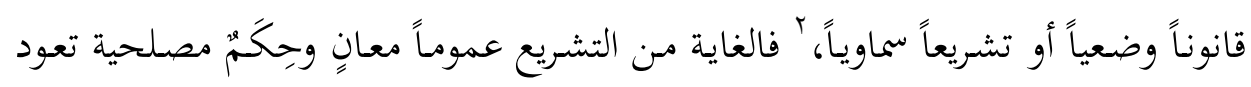

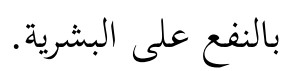

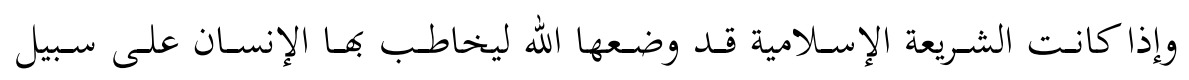

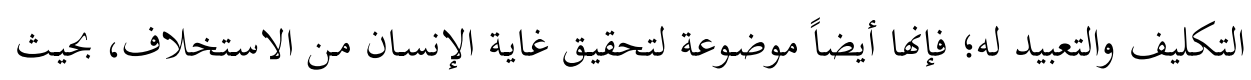

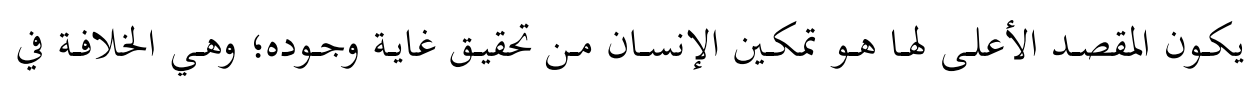

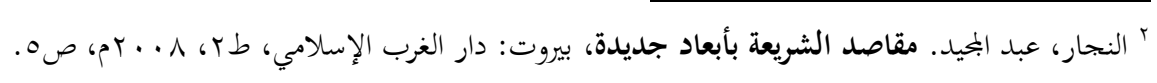




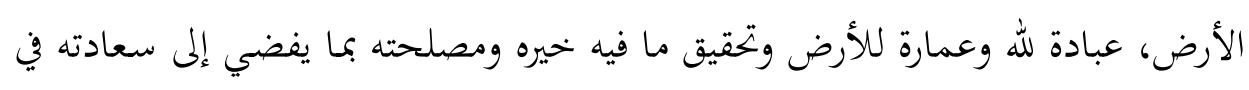

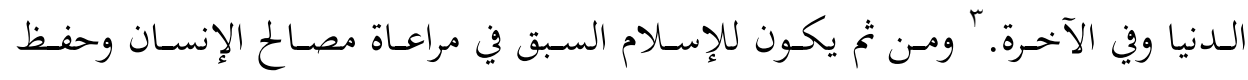

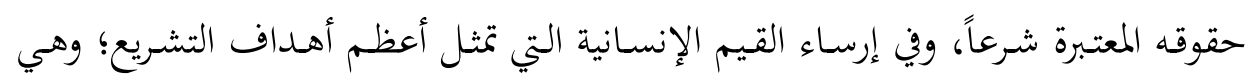

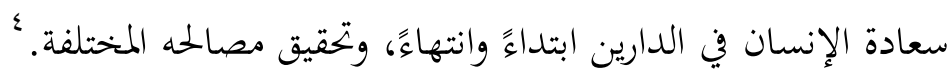

لقد وُضعت الشريعة للمحافظة على الضرورات الخمس وهي: الدين والنفس والنسل

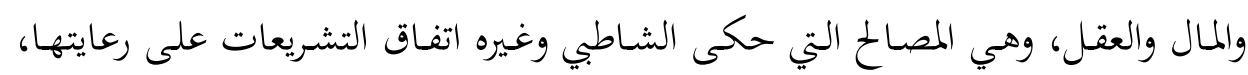

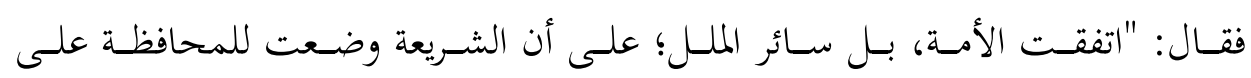

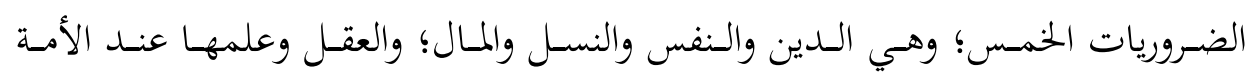

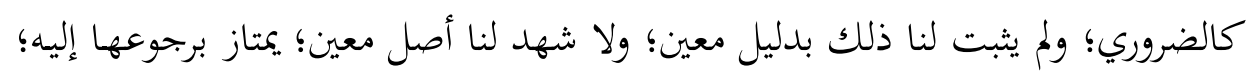

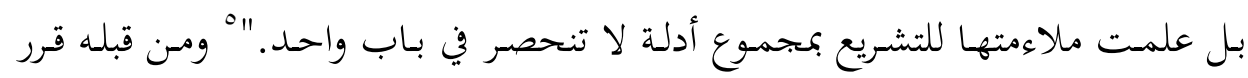

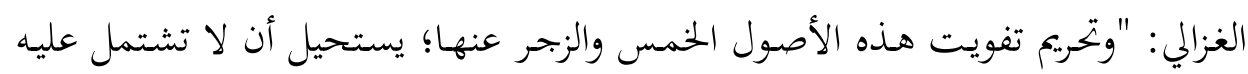

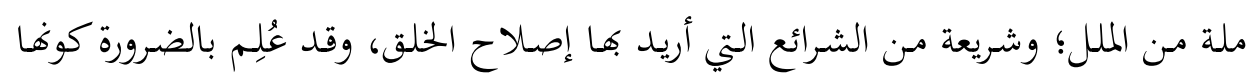

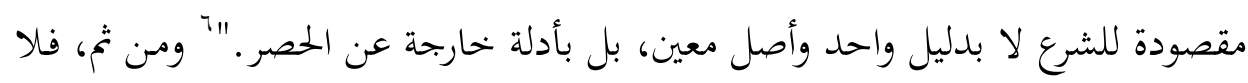

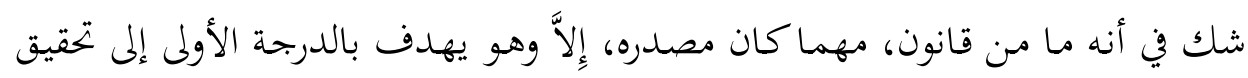

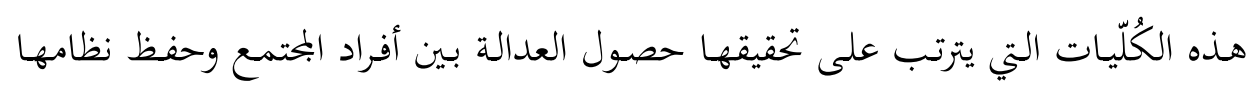

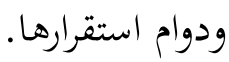

ولكن رغم إقرار فقهاء القـانون بأولوية هذه المقاصد في الرعاية القانونية والحماية

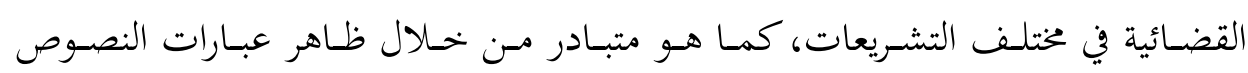

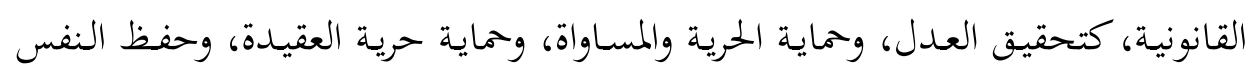

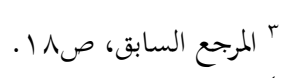

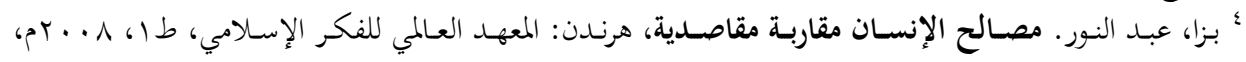
صمان. ما الشاطبي، إبراهيم بن موسى. الموافقات في أصول الشريعة، تحقيق: أبو عبيدة مشهور بن حسن آل سلمان، دار

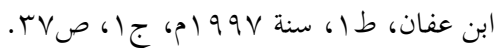

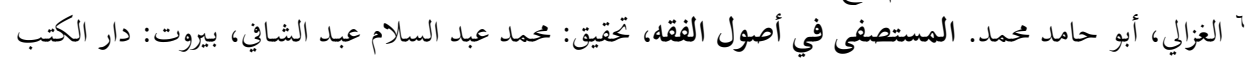

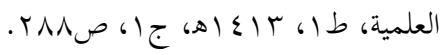


والعقـل والعـرض والنسـب والمـال مـن خـلال تقسـيمات الجــائم إلى جـرائم واقعـة على

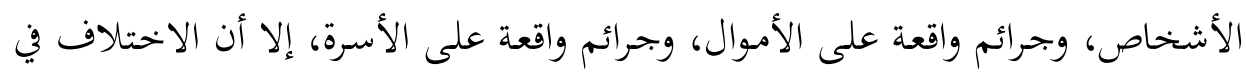

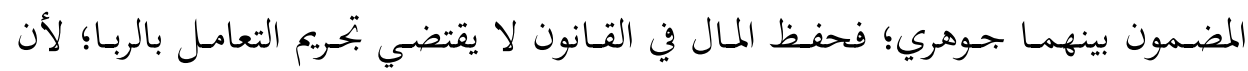
المقصد تحقيق الربح بكل وسيلة غير بحرمة، بخلاف الشريعة، فالمقاصد لا تبرر الوسائل. وحفظ الدين في القانون لا يقتضي بتحيم الردة. وحفظ العرض لا يقتضي بتحيم الزنا بكل صورها. وحفظ العقل لا يقتضي تجريم شرب الخمر.

ومسن ثم يكون التشابه في تقرير هذه المقاصد والقيم المصلحية ظاهري ولفظي، ولا يقتضـي عنـــ التحقيـق الموافقـة التامـة بينهمـا، للاخستلاف الجـــري بينهمـا في المصــادر والأصول؛ فهو بالنسبة للشريعة الوحئ المعصومُ بشقيه؛ وهو في القـانون العقلُ الجمعي، بقصوره ونسبيته، كما أن ذلك التشابه المتبادر سرعان ما يتبخر عند المقارنة بين المقصد العام للشارع من تشريعه الأحكام والمتمثل في كفالة ضروريات الناس، وتوفير حاجياقم

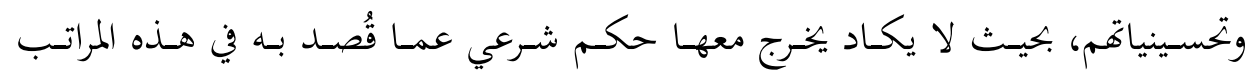

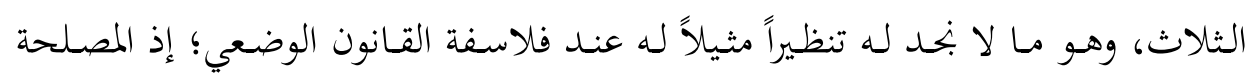

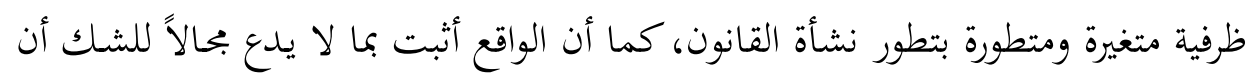

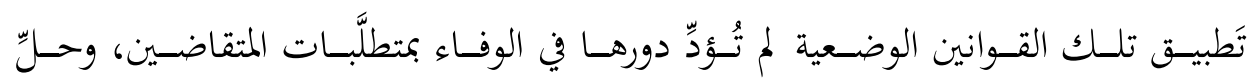
خصوماقم. وترتيباً على ذلك فإن أهداف التشريع الوضعي رغم قيميّتها إلا أن القواعد المرصودة

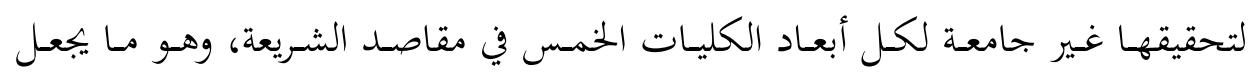
القانون الوضعي قاصراً عن تحقيق مصالح الناس، وجلب النفع لهم، ودفع الضرر عنهم، وعندئذ تكون نظرية المقاصد الشرعية هي الملجأ في سد هذا القصور والإغفال التشريعي، ومـن ثم يعوّل الفقـه القـانوني كثيراً على تفعيـل نظريـة مقاصــ القـانون كخطط تشـريعية يهتدى بها في إدراك مراد المُشرّع، في ظل تدلي غالبية القوانين المعاصرة من حيث النوعية وغياب الوضوح ونقص في المعيارية القيمية. 
ومع ذلك يلاحظ الباحث أن فكرة المقاصد في التشريع الوضعي ليست مغيّبة كليّة،

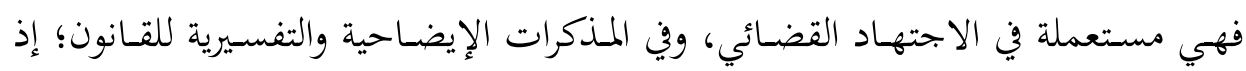

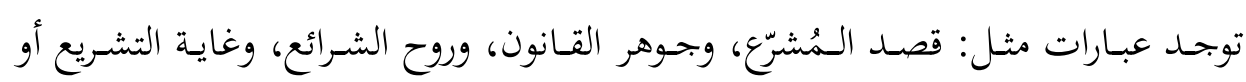

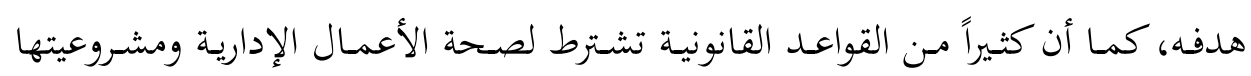

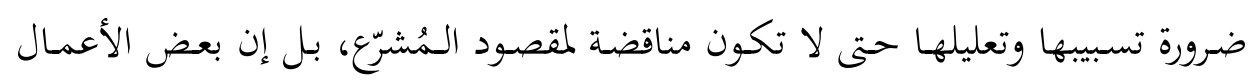

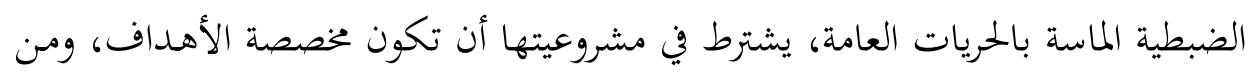
تم فهي فكرة مقررة ضمن مباحث فلسفة القانون تحت مسمى "روح القانون".

\section{1 ا ـ روح القانون من منظور مقاصد التشريع الإسلامي:}

من الحقائق العلمية أن وراء كل قاعدة قانونية اعتبارات غائية تتحكم في وضعها؛

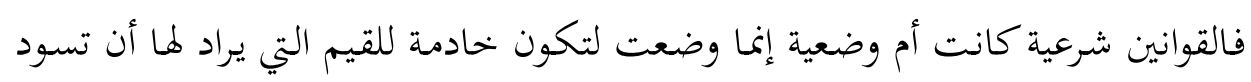

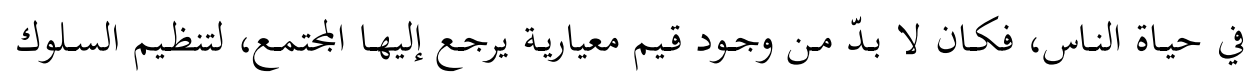

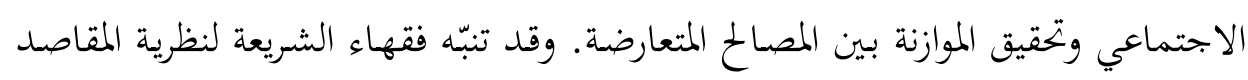

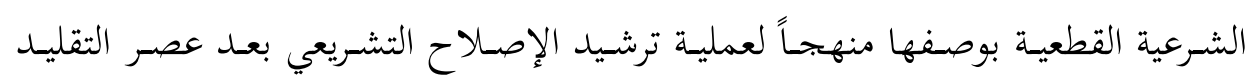

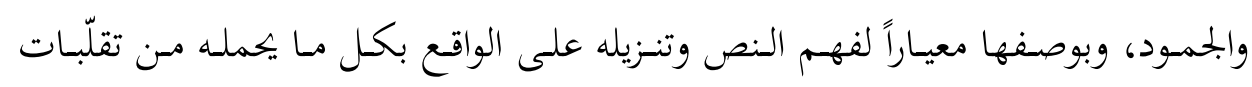

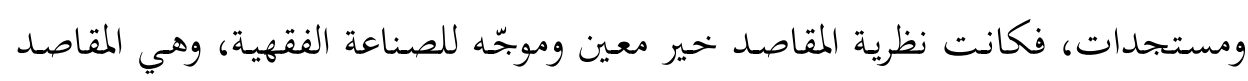
التي تفتقر إلى مثلها التشريعات الوضعية؛ إذ يكون القانون غالباً انعكاساً ظرفياً، وبعيداً

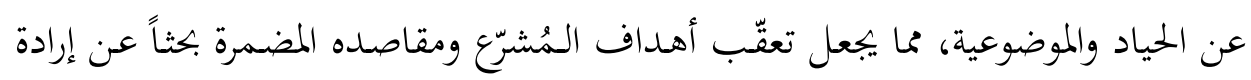

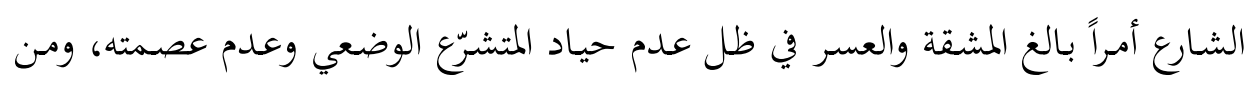

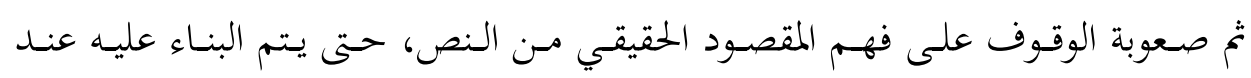

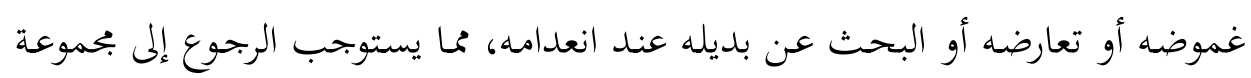
القيم التي يستهدفها كل قانون، وتلك هي مدرسة فلسفة القانون.

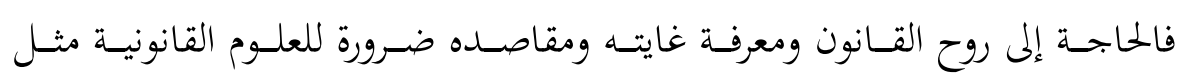

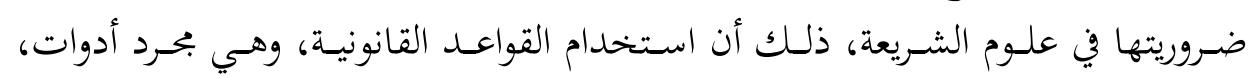




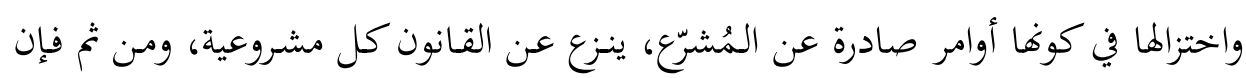

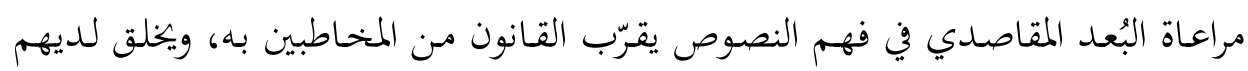

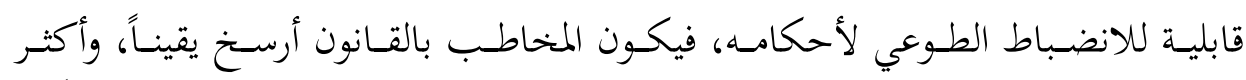

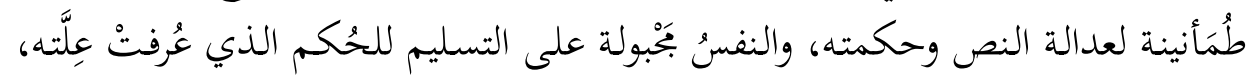

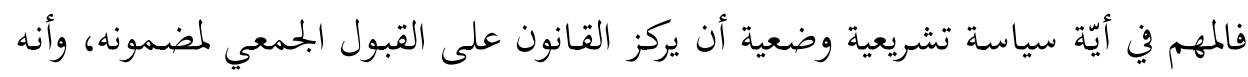

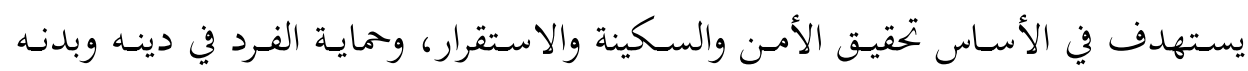

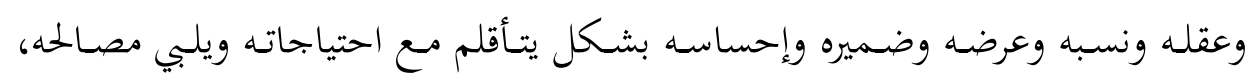

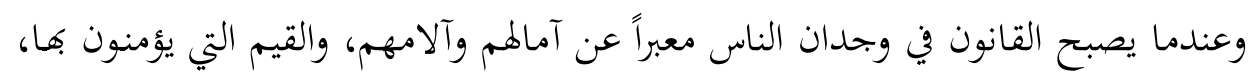

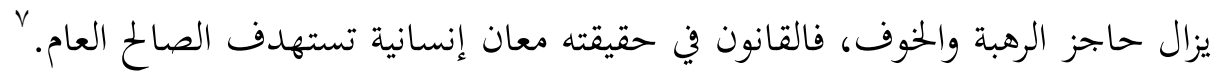
وعلى اعتبار أن المقاصد لا تبحثث في الأحكام، ولكن في ثمرات الأحكام ومآلاتها، وهو أهم تشوفاً لدى الشارع من الاهتمام بمجرد معرفة الأحكام ذاتها، يقول الشاطبي:

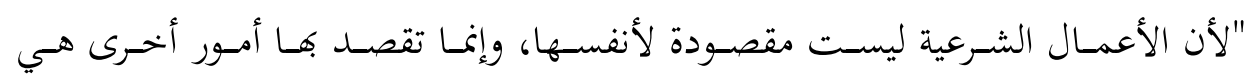

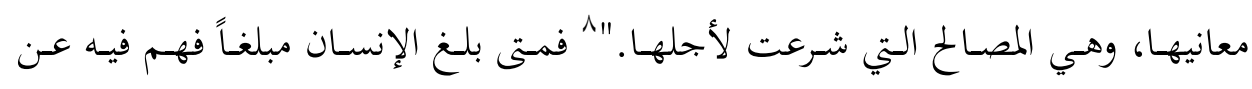

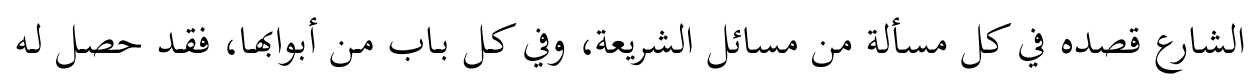

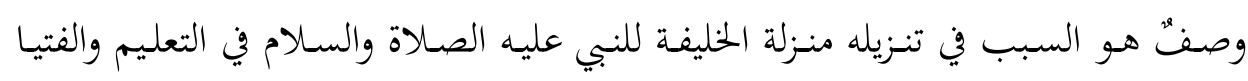

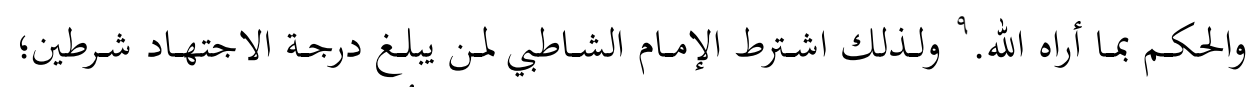

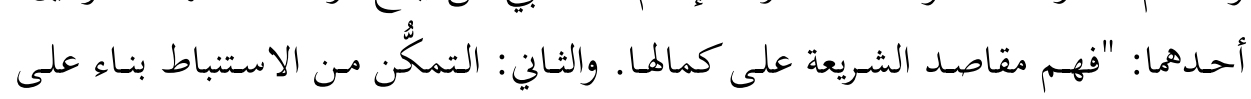

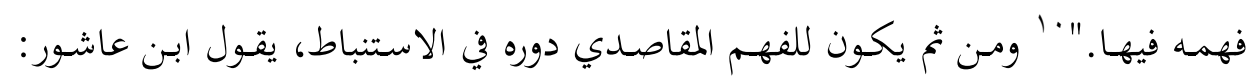

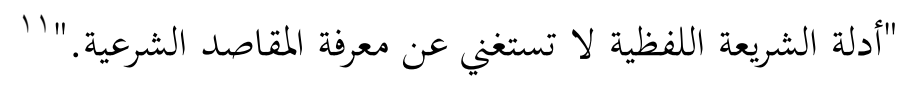

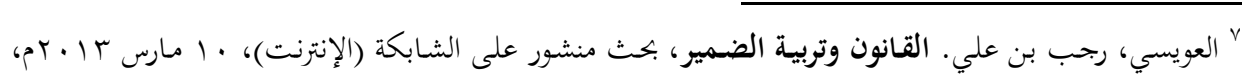

- http://alhwaraleegabe.blogspot.com

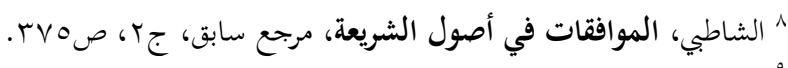

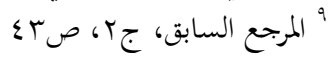

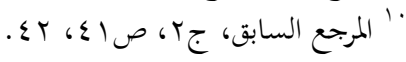

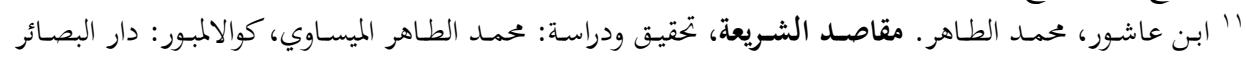

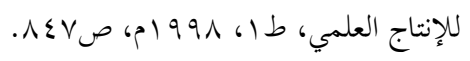




\section{r. علاقة نظرية القيم بروح التشريع الوضعي:}

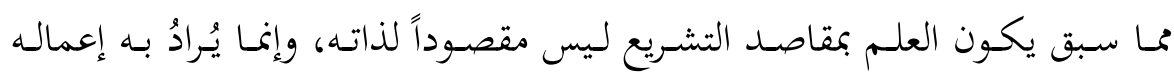

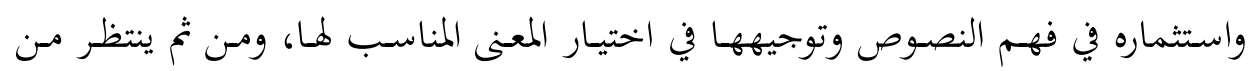

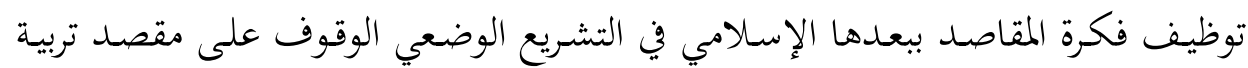

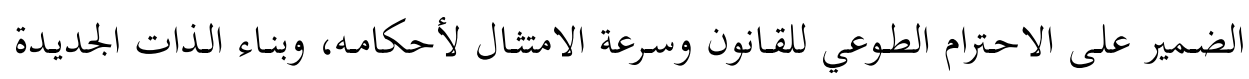

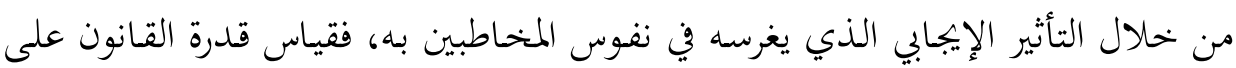

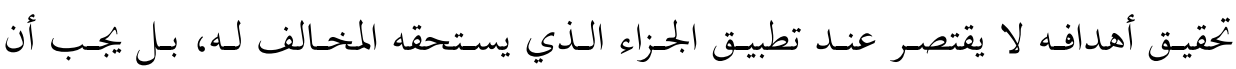

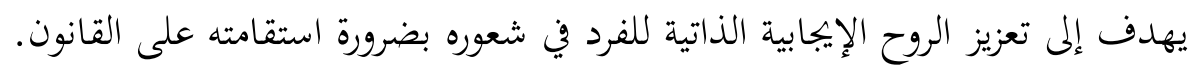

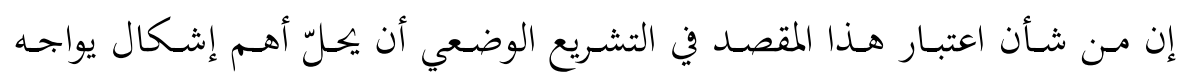

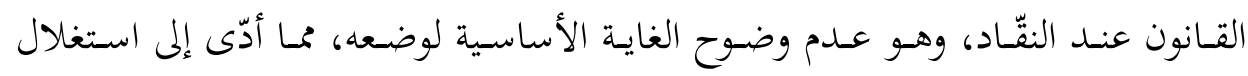

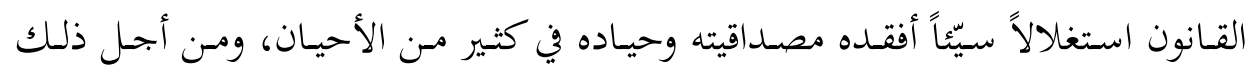

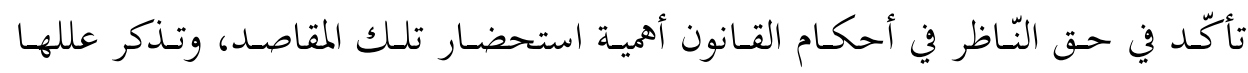

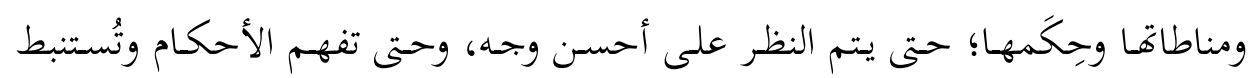

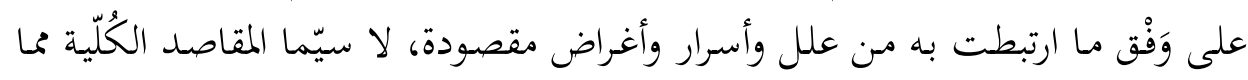

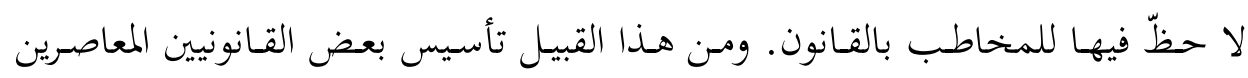

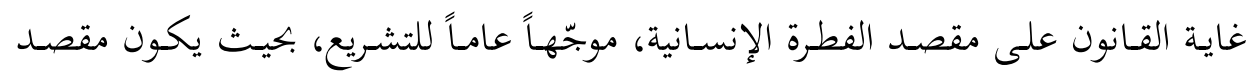

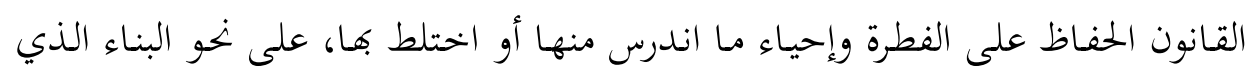

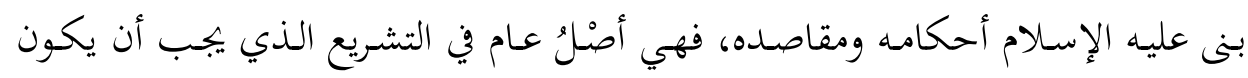

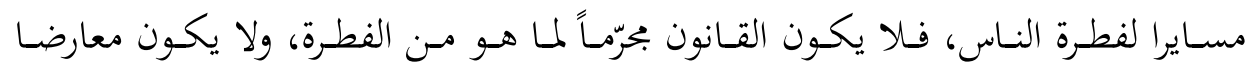

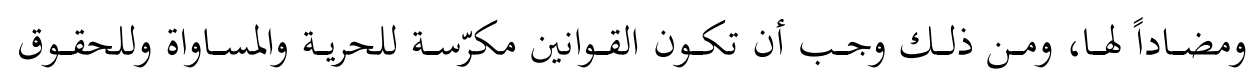

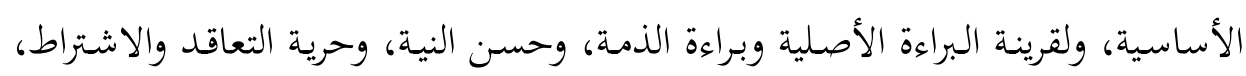

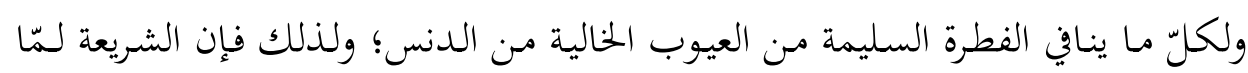

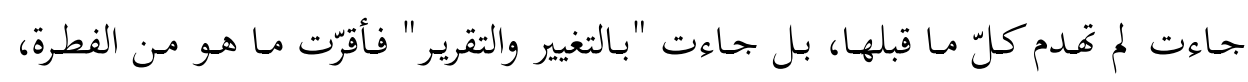

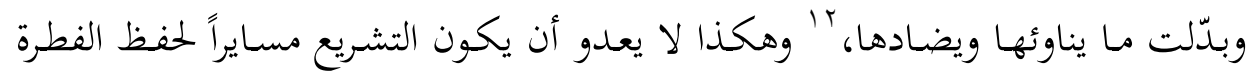




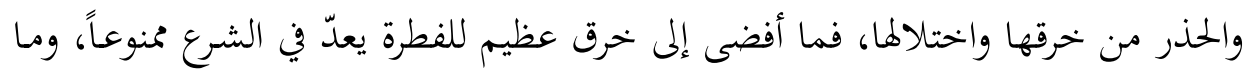

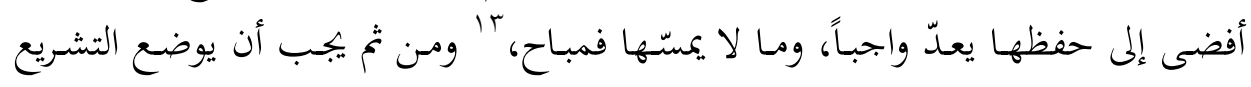
على الوجه الأعدل والأوسط.

غـير أنه رغـم هـا التوظيف الإيجـابي لمنظومـة المقاصــ في فهـم النصـوص القانونيـة

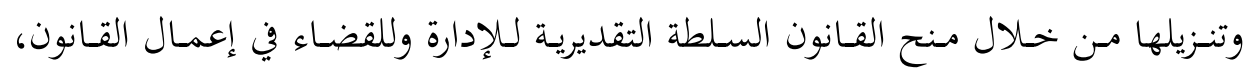

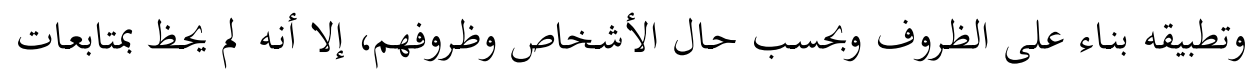

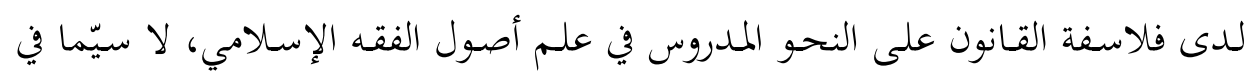

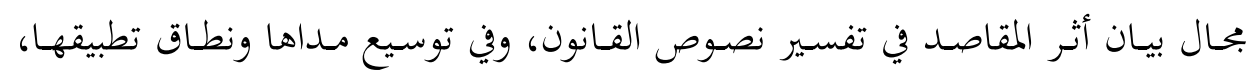

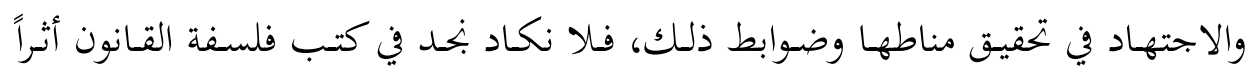

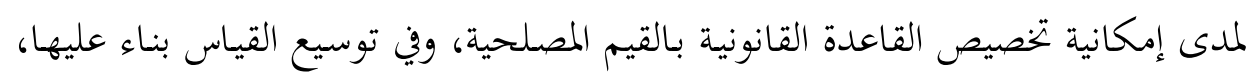

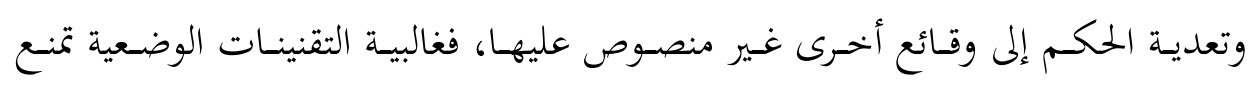

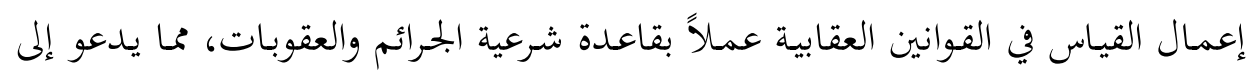

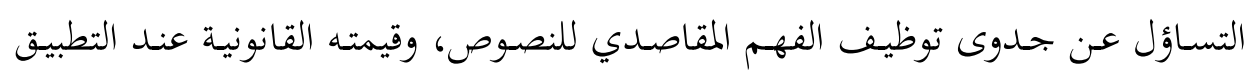
والتنزيل.

\section{ثانياً: الفهم المقاصدي للنصوص الشرعية والوضعية}

مما سبق تعدّ المقاصد بمثابة جوهر التشريع وأساسه، فاستقراء تفاصيل الشريعة يؤكد

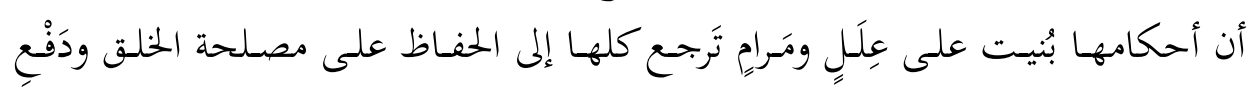

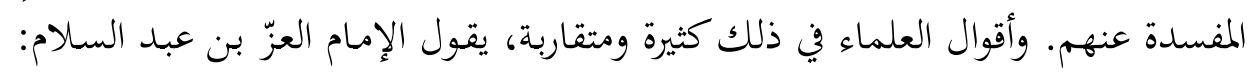

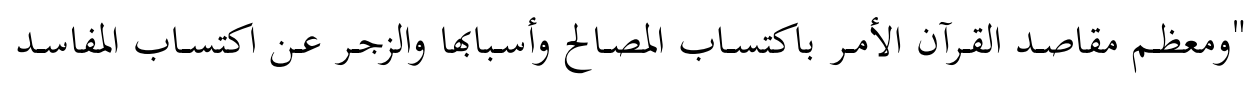

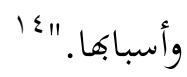

rا1 شام، بشير. فلسفة التشريع الإسلامي في ضوء مقاصد الشريعة، بحث منشور على الشبكة العنكوتية، تاريخ - http://www.alhiwar.net

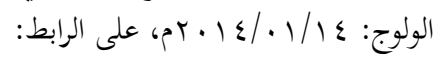

צ' ابن عبد السلام، العز. قواعد الأحكام في مصالح الأنام، بيروت: دار الكتاب العلمية، بو9 (م) ج)، صلا. 


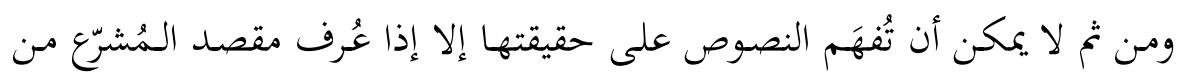

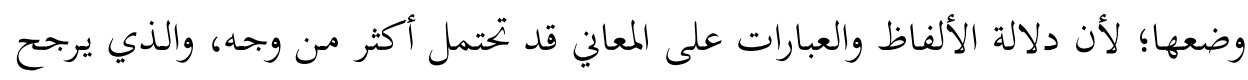

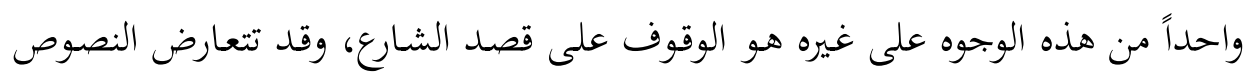

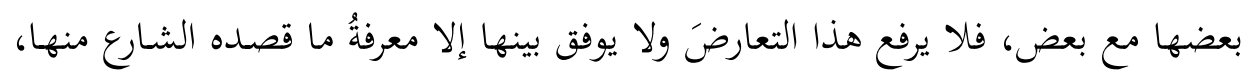

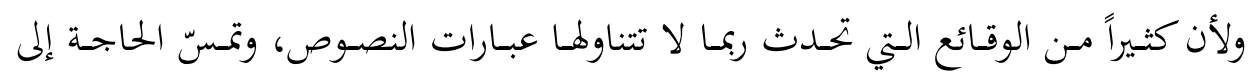

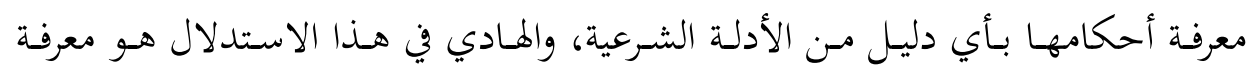

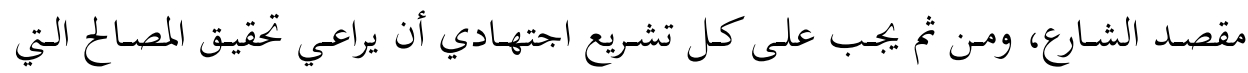

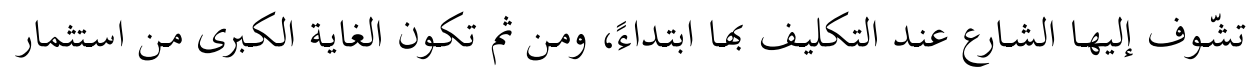

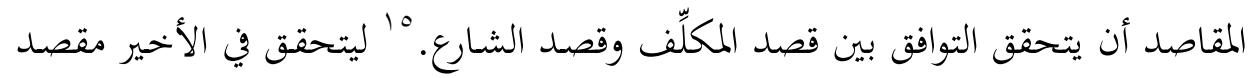

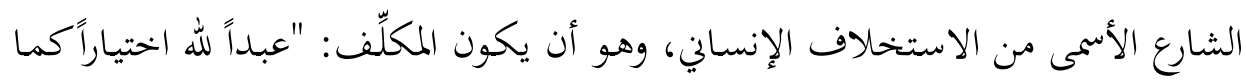

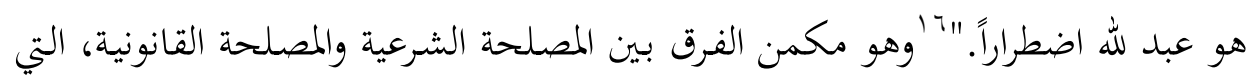

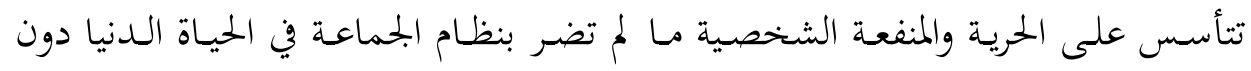

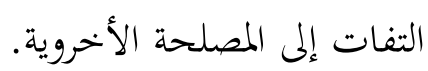

\section{1. فلسفة نظرية المقاصد الشرعية:}

أهمية إعمال النظر المقاصدي في فهم النصوص الشـرعية معلومة ثابتة عند أعلام

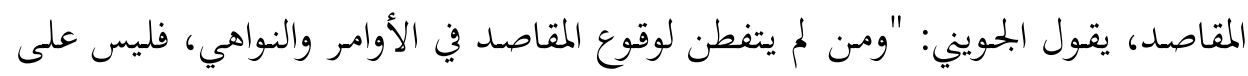

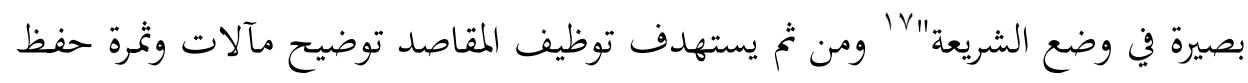

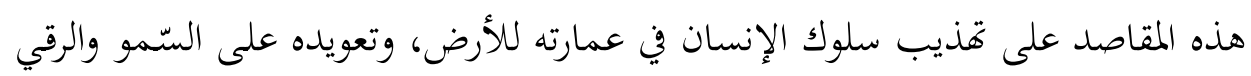

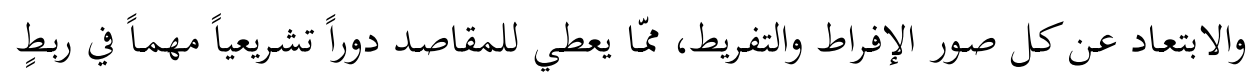

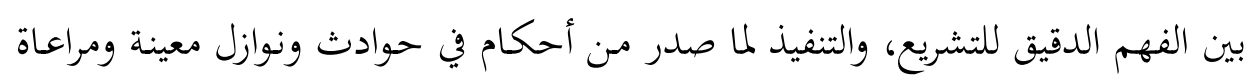

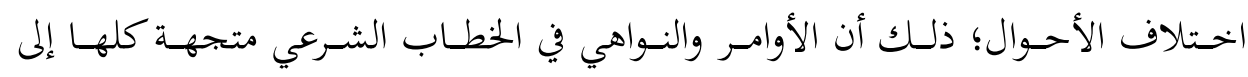

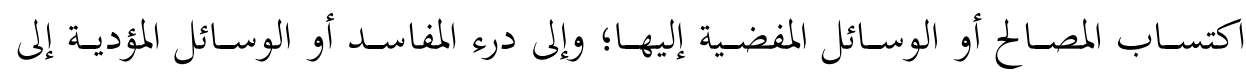

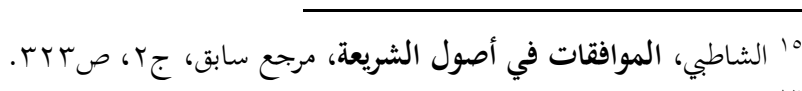

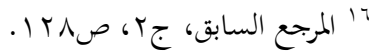

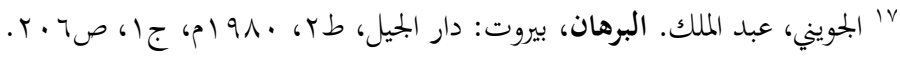




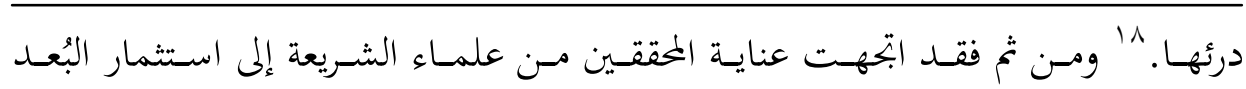

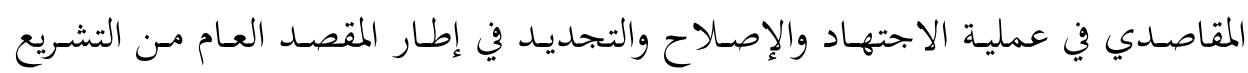

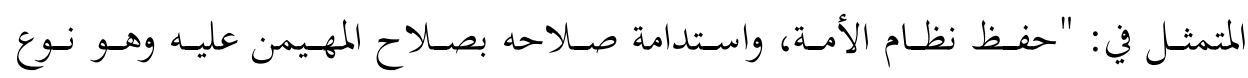

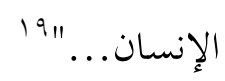

ومـن هنـا يجـب أن يكـون واضحاً للدى القـائمين بالمهام الاستخلافية في الأمـة، أن مقصود أعمالهم وتصرفاقم في الرعية منوطُ بتحقيق الصلاح العمراني المفضي إلى الصلاح الفردي والجماعي، ذلك أن الشريعة كما يقول الإمام علّلال الفاسي أحكام تنطوي على

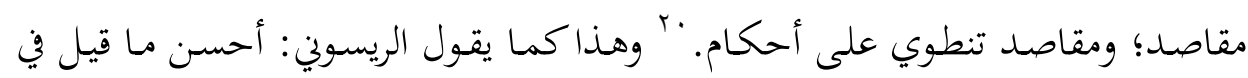
تصـوير وتقريـر علاقـة المقاصــ بالاجتهـاد والاسـتنباط، ذلـك أن المقاصــ تؤخسـ مـن الأحكام، وأن الأحكام تؤخذ من المقاصد؛ بأن ننظر في الأحكام فنستنبط منها المقاصد

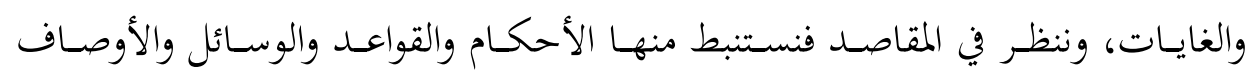

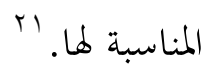

ومن ثم يجب استحضار البعد المقاصدي والالتفات إليه في عملية التشريع، ويي بيان الأحكام وتطويرها والترجيح بينها، من خحلال الربط بين كلياته وجزئياته ودلالة نصوصه على معانيها، فضلاً عن توظيفه أثناء الاجتهاد التنزيلي للأحكام، وذلك بتحقيق المناط،

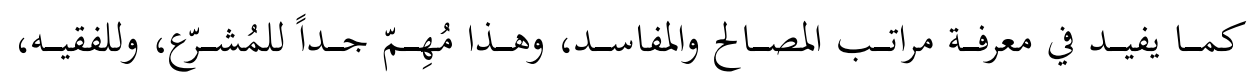
وللقاضي، عند الموازنة بين مختلف الخيارات المتاحة أمامه، وهو المستفاد من أقوال فقهاء الشريعة، يقول ابن تيمية: "والمؤمن ينبغي له أن يَعْرف الشرور الواقعة ومراتبها في الكتاب

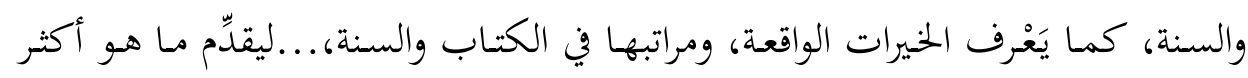
خيرًا وأقل شرَّا على ما هو دونه، ويَدْفع أعظم الشريّن باحتمال أدناهما، ويَجْتلب أعظم

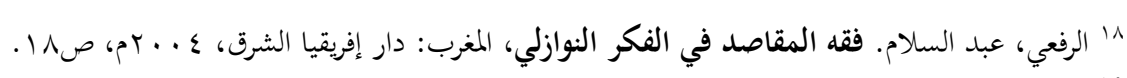

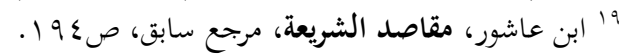

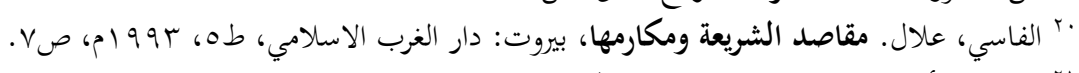

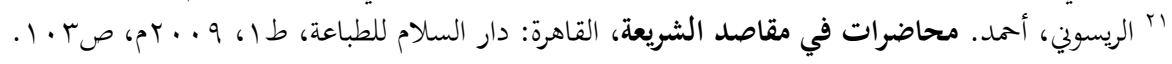




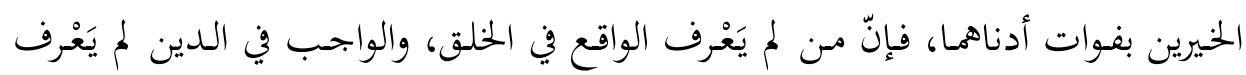

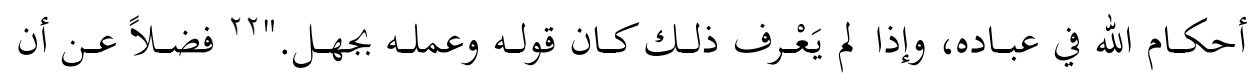

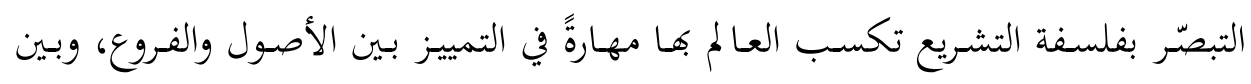

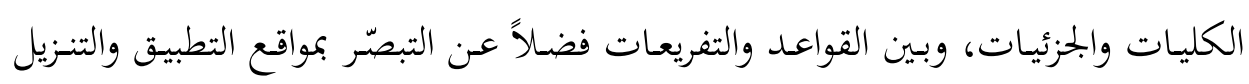
ومآلاته.

ومن ثم يكون لقاعدة المصلحة أثرها الفعّال في التطبيق المقاصدي للأحكام الشرعية،

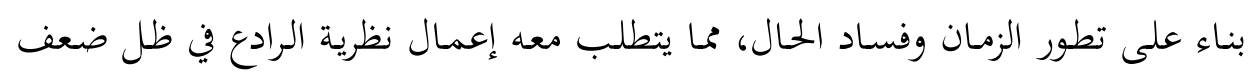

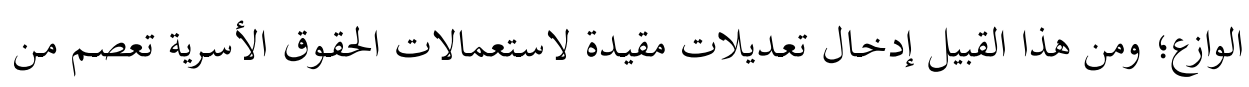

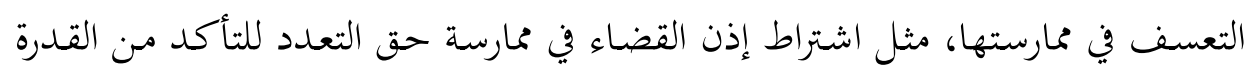

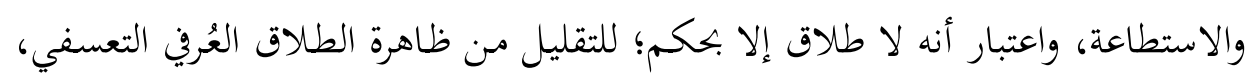

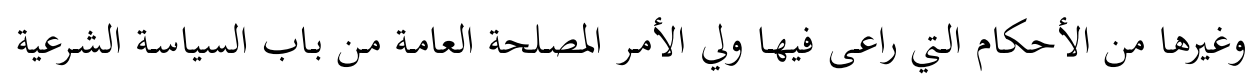

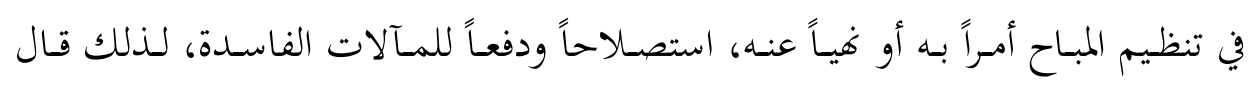

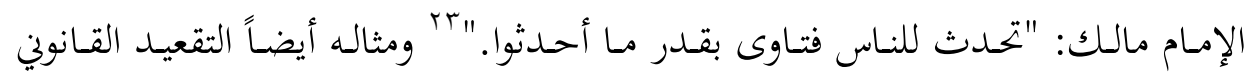

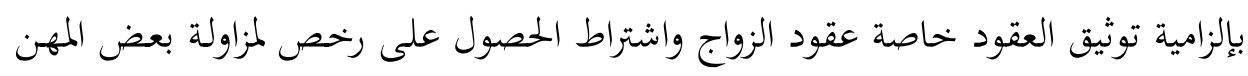

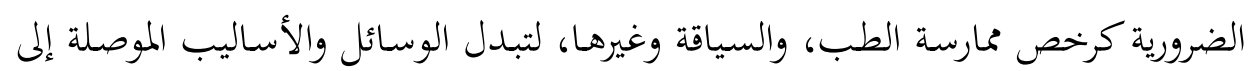

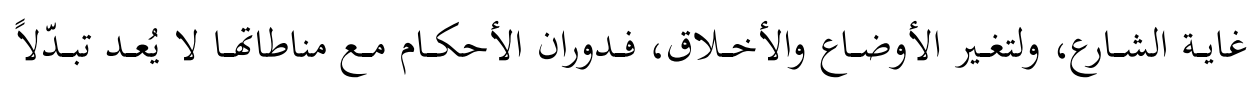

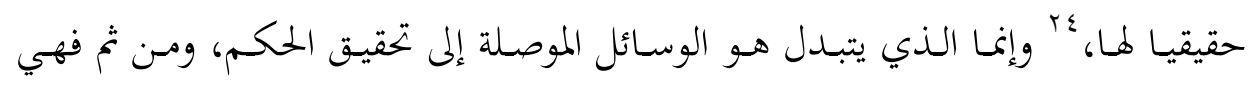

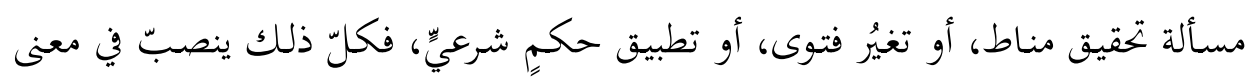

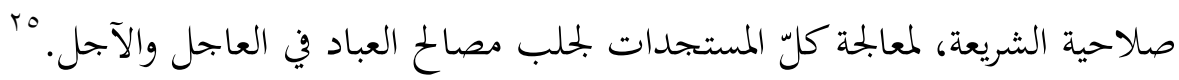

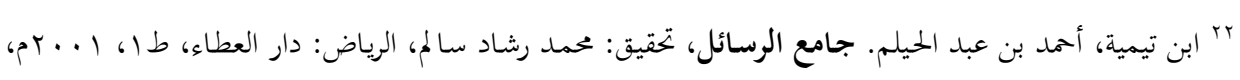

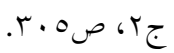

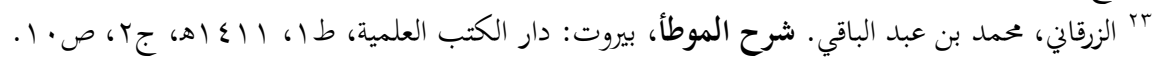

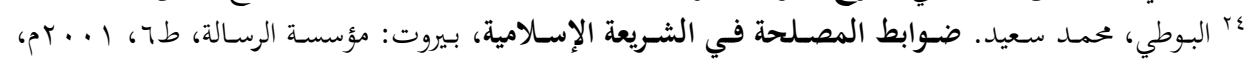

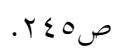
Po القرضاوي، يوسف. شريعة الإسلام خلودها وصلاحها للتطبيق في كل زمان ومكان، الدار البيضاء: دار المعرفة،

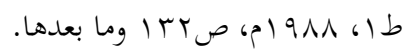




\section{Y. فلسفة مقاصد التشريع الوضعي:}

الفلسفة علم العلوم، فمنها تتغذى الأصول والمقاصد، وبها تتجدد الفروع والقواعد،

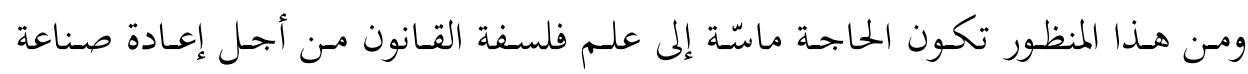

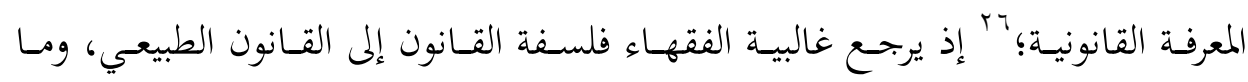
يتضمنه من حقوق طبيعية فطرية سابقة الوجود على القانون، ويجب على جميع الشرائع

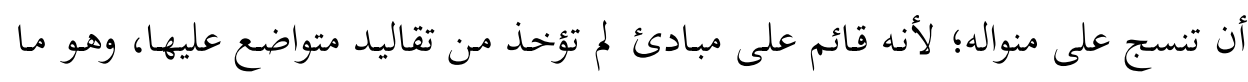

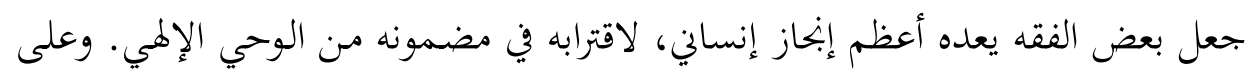

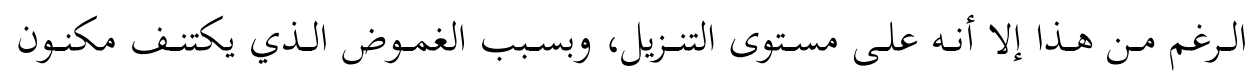

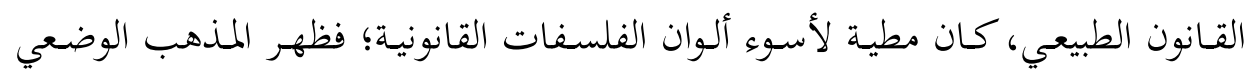

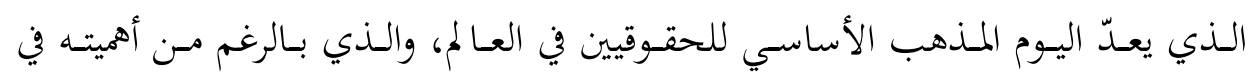
الضبط الاجتماعي فإن إدراك مقاصده وقيمه المثلى يبقى أمراً مضطرباً وغير ذي أولوية

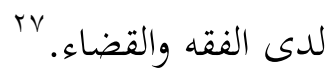

ولم تعـدم الدراسـات القانونيـة تصسور بعض المقاصــ التي يجـب أن يتغيّاهـا الـمُشرّع والقاضي، ويشهد لذلك ظهور عددِ من المدارس القانونية الفلسفية، مما يؤدي إلى القول

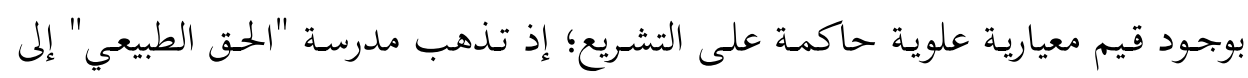

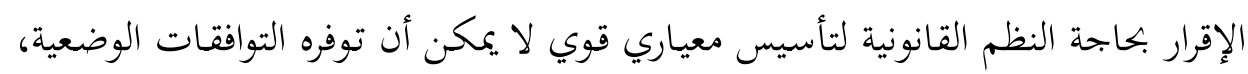

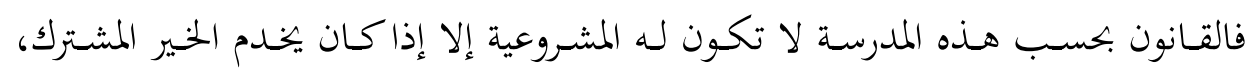

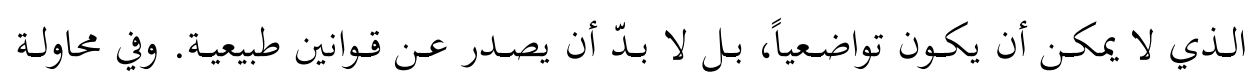

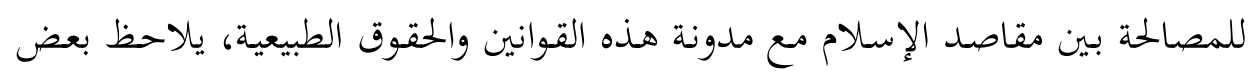

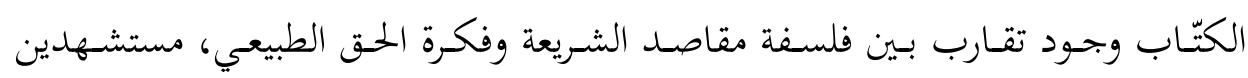

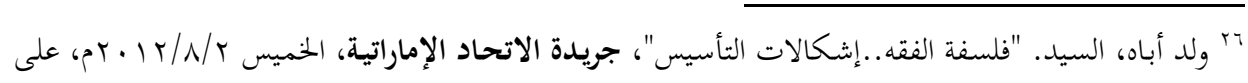

- www.alittihad.ae/wajhatdetails.php?id=69269

VY عبد الوهاب، صلاح الدين. الأصول العامة لعلم القانون -نظرية القانون-، الأردن: مكتبة عمان، 971 (م)، 


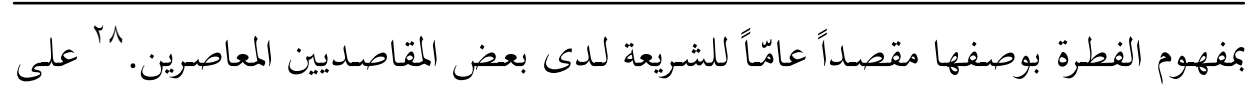
أن الاشـتراك بـين الشـريعة الإسـلامية والقـانون الوضـعي في بعضض الجزئيـات لا يسـتلزم تفريغها من ذاتيتها وفلسفتها الإصلاحية والأخلاقية، دون محاولة افتعال المصالحة التامة بينهما؛ لأن الفروق بينهما تبقى أساسية في المصدر والوجهة.

ومن بين التطبيقات القانونية والقضائية المهمة في إعمال الفهم المصلحي للنصوص

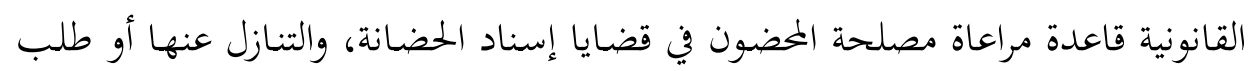
إسقاطها أو الرجوع عنها، فتـد عـدّت غالبية التشريعات الأسرية العربية أن كل إسـناد للحضانة أو تنازل عنها من شأنه أن يهاد مصلحة المخضون لا يعتدّ به، وعلى القاضي مهمة تقدير المصلحة، بل يمكن للقاضي أن يجبرها على الحضانة في حالة عدم وجود من يجضن الطفل، "متى أضر التنازل بمصلحة المحضون"، وللاعتبار نفسه فلا مانع من إعادة إسناد الحضانة إليها بعد تناولها، إذاكانت مصلحة المحضون تتطلب ذلكن، منكا يستفاد

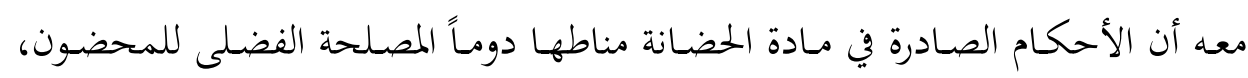

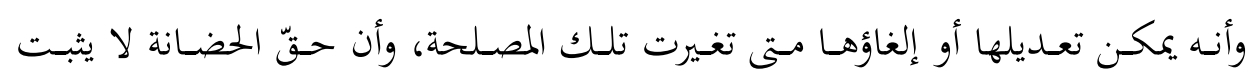
للحاضن بصفة مؤبدة، وإنما يدور مع مصلحة المحصون وجوداً وعدماً.

\section{ثالثاً: ذاتية المصالح المعتبرة بين فلسفة التشريع الوضعي ومقاصد الشريعة} إنّ قياس الأمور بمعيار الفائدة والمصلحة ركنٌ من أركان الحكمة الإنسانية الأساسية، ومن ذلك أن الشرع الإسلامي مبني على طلب المصلحة ودفع المضرة، فمن هذه الزاوية

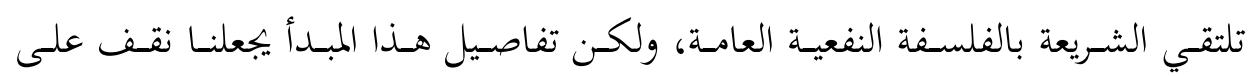

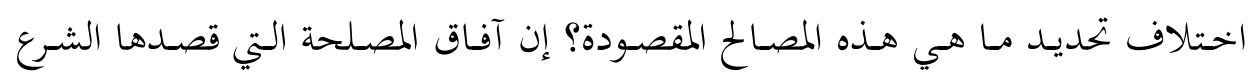

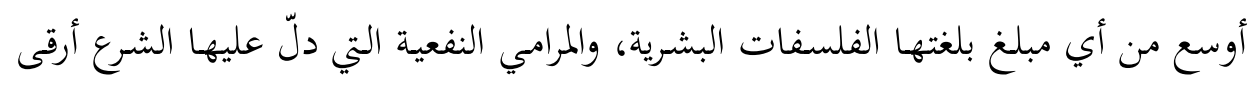

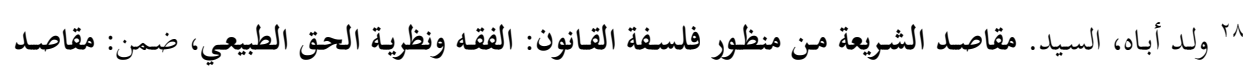

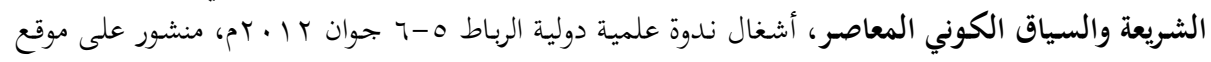

- http://www.massarate.ma

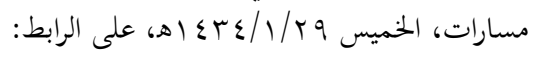




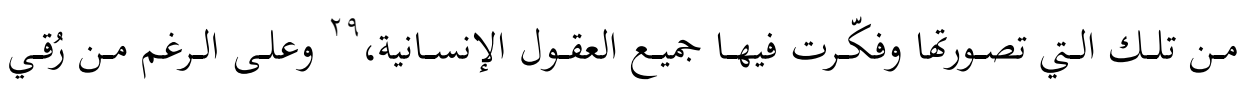

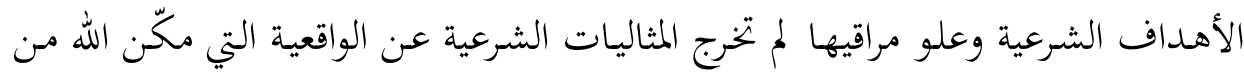
بلوغها قدرة بني البشر، فجميع الأمـم تضع القوانين والدساتير على أساس تحقيق العدل

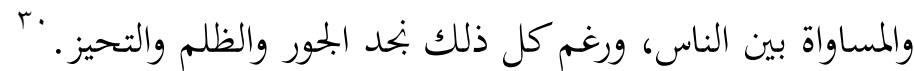

\section{I ـ رعاية المصلحة في التشريعين الوضعي والإسلامي:}

للمقاصد والمصالح المعتبرة دورُ المقورج في عملية الإصلاح التشريعي، ومـن ثم كانت

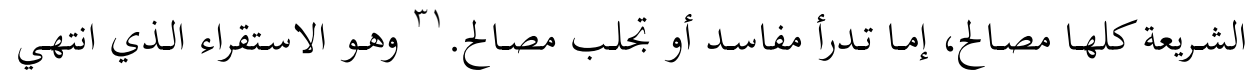

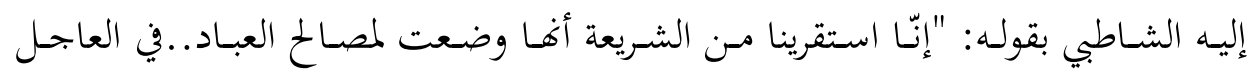

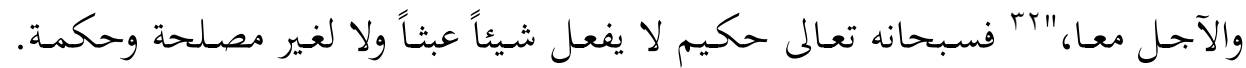

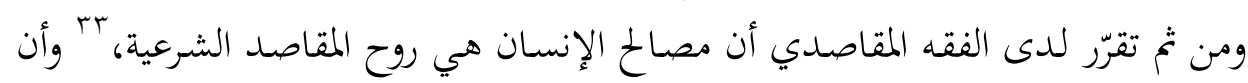

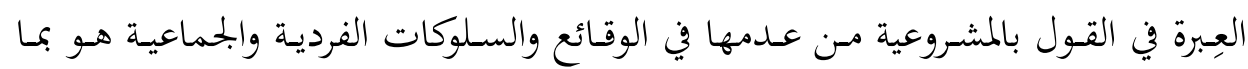

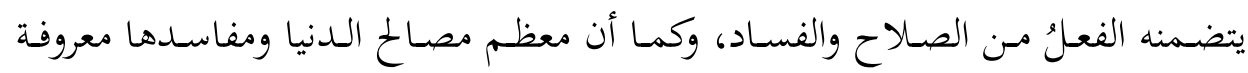

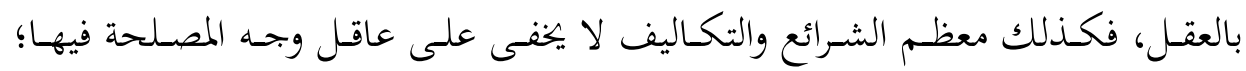

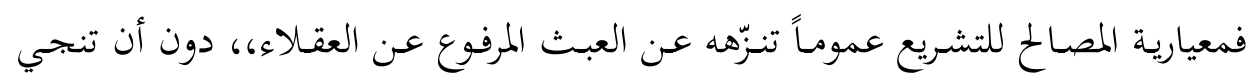

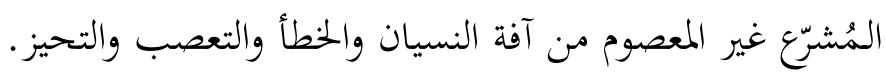

إنّ عدم وضوح نظرية المصالح في التشريع الوضعي وعدم اكتمال نضوجها، جعلت

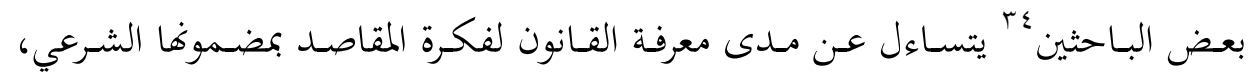
9جr جيوانتو، فهمي إسلام. سمو المقاصد الثرعية بين الفلسفة النفعية والدور الرسالي ومقام العبودية، ضمن:

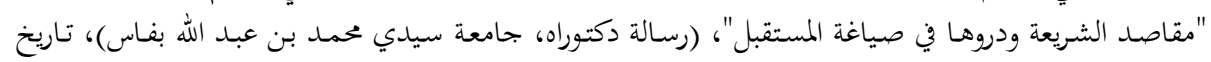

- http://afaqmostaqbal.wordpress.com/2012/03/27

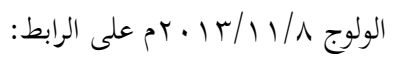

•r دعبل، نفيسة. "الموازنة بين حرفية نص القانون وروحه مطلدبّ لأنسنة القـانون"، صـحيفة الوسط البحرينيـة،

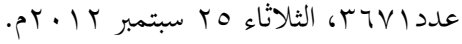

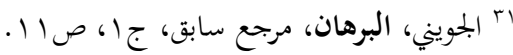

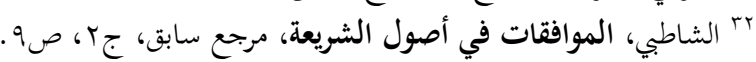

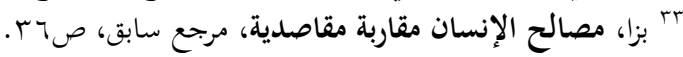

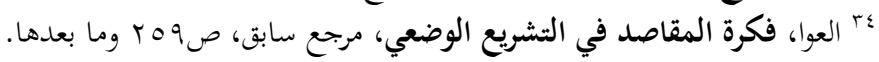




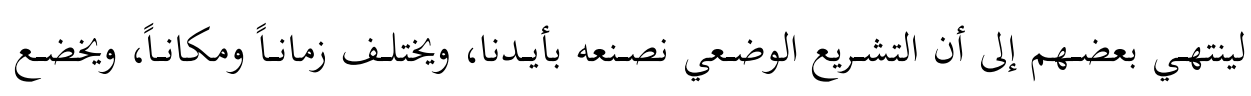

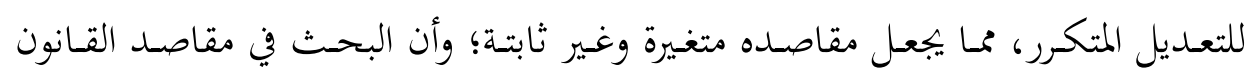

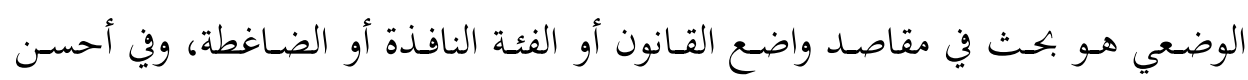

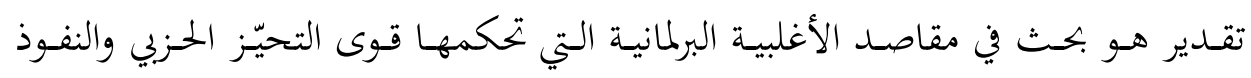

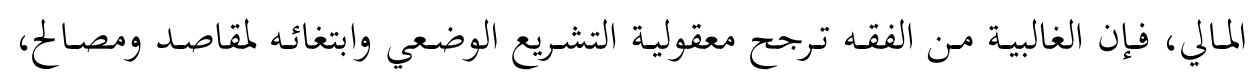

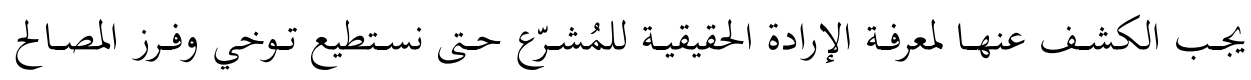

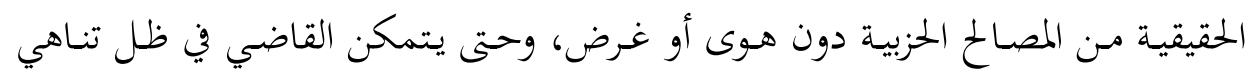

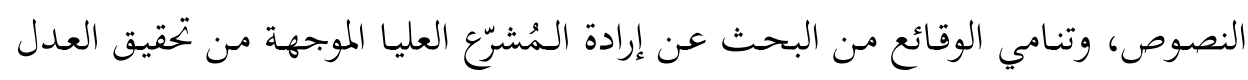

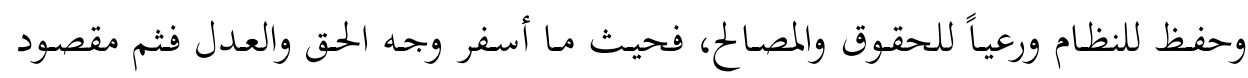

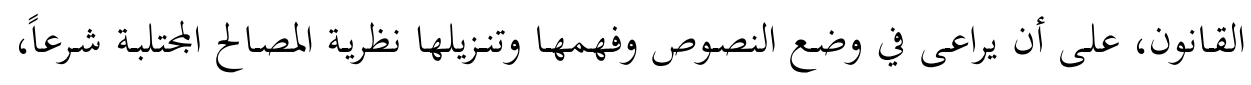

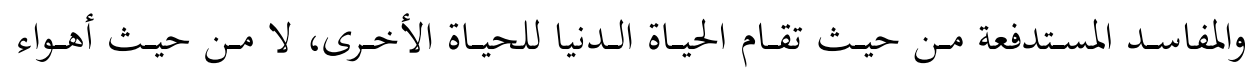

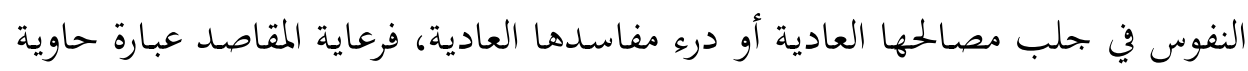

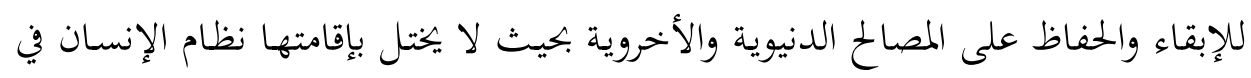

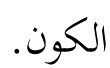

\section{Y.ضوابط المصلحة في الفكرين الوضعي والإسلامي:}

من الواجب التنبيه إلى ملحظ دقيق عند مقاربة مقاصد القانون من مقاصد الشريعة

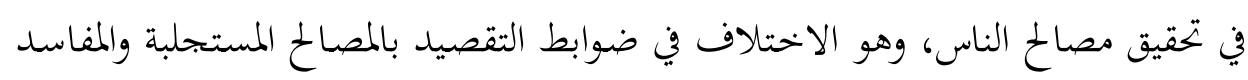

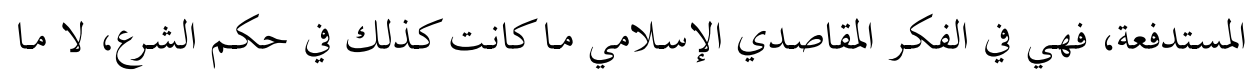

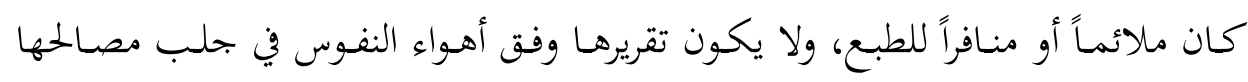

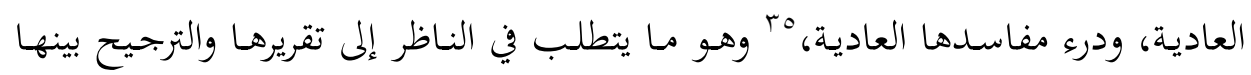

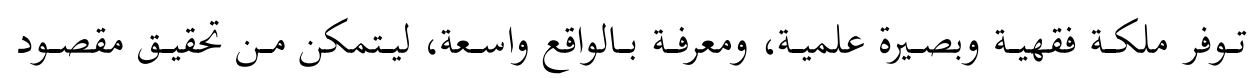

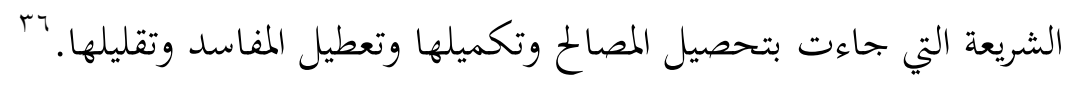

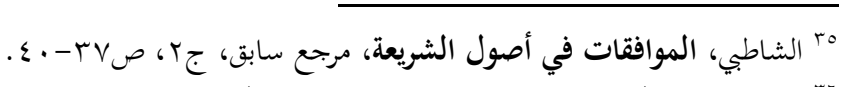

$$
\begin{aligned}
& \text { "بr شمام، فلسفة التشريع الإسلامي في ضوء مقاصد الشريعة، مرجع سابق. }
\end{aligned}
$$


ومن ثم فلا حُجّة لمن يتكئ على نظرية المقاصد لاستبعاد النصوص القطعية الدلالة بدعوى أن الحاكمية لروح الشريعة ومقاصدها لا لحكمها ومنصوصها، ذلك أنّ المصالح

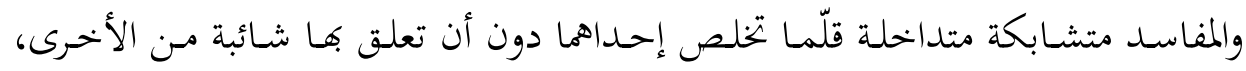
ومن ثم فعلى من يتصدى للتشريع والفتوى والقضاء أن يبذل الطاقة في التوصّل إلى موازنة

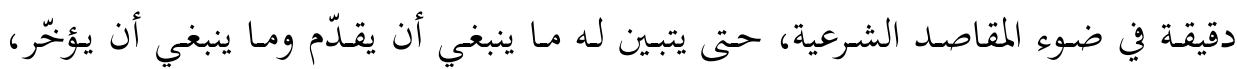

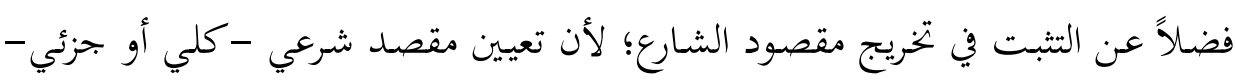
أمر تتفرع عنه أدلة وأحكام كثيرة في الاستنباط، ففي الخطأ فيه خطر عظيم..."

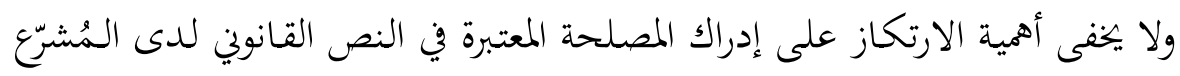

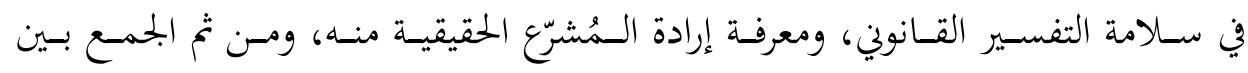

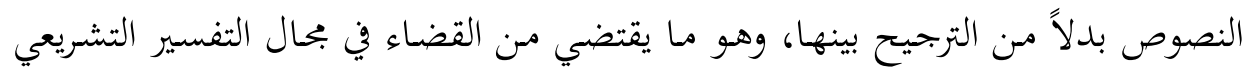

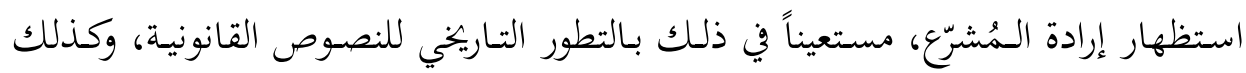

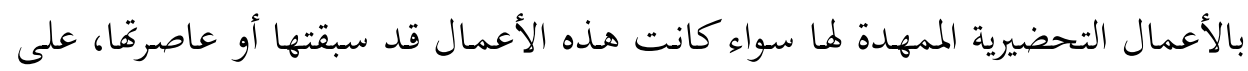

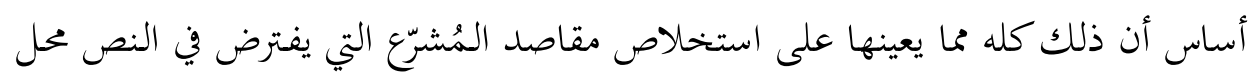

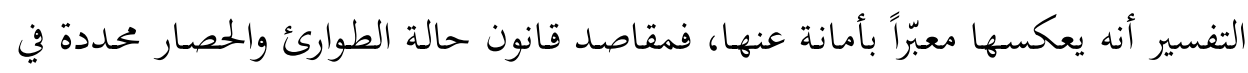

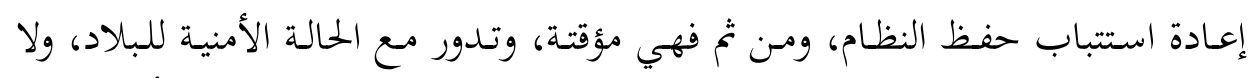

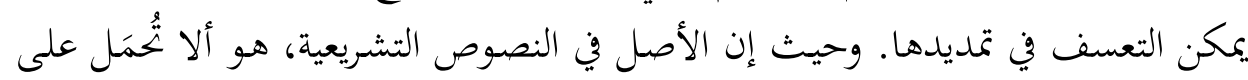

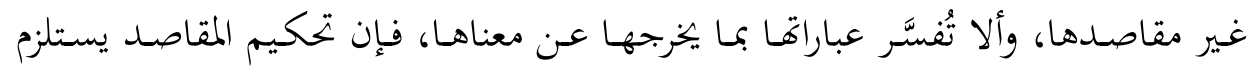
تقرير أن الاضطرار لا يسقط حق الغير، وإنْ لمُ ينص عليه قانون الطوارئ.

وبخصوص ضوابط المصلحة المعتبرة قانوناً، فإنّ الأصل أن كلّ ما فيه منفعة للفرد فهو

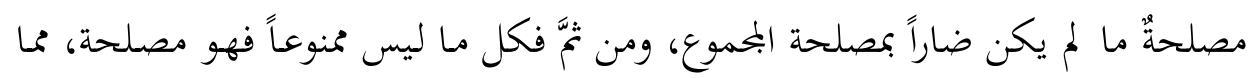
يعطي مشروعية لتوظيف مقاصد القانون المصلحية في فقه التنزيل، وفق قاعدة، "حيثما توجد المصلحة فثمّ شرع الله"، وهنا يظهر التوافق بين الشرائع السماوية والقوانين الوضعية في إدراك العقـل للمصـالح والمفاسـد غير المنصـوص عليها، مـع الفـارق في ضـوابط اعتبـار العقل للمصلحة فيهما، فهي في الشريعة يجب أن تكون ملائمة لمقاصد الشريعة، يقول 


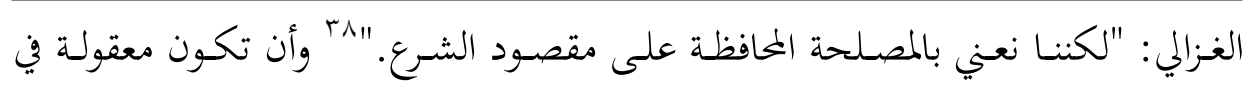

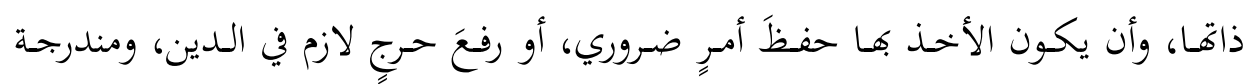

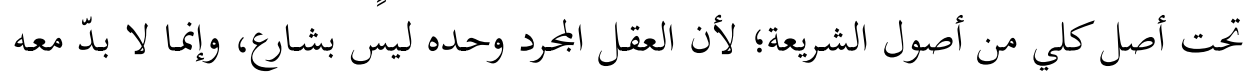

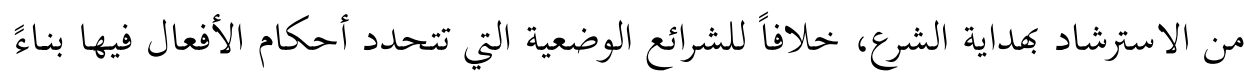
على ما يقرره العقل المحرد، بما يظهر له من وجوه المنافع التي يحتكم إليها، يقول الغزالي:

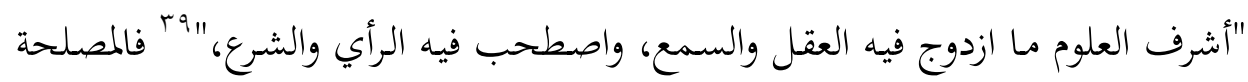
القانونية لا تتفق في كثير من جوانبها الأساسية مع المصلحة المعتبرة شرعاً مثل تجريم الزنا

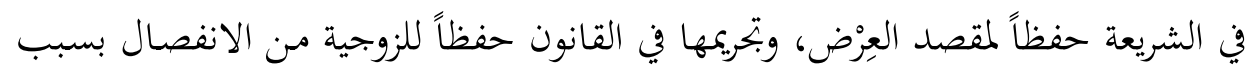

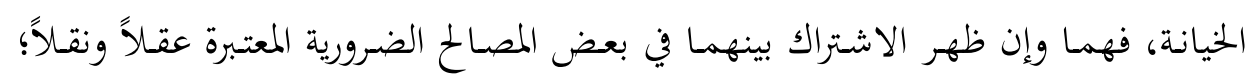
إلا أن الفروق بينهما واضحة في تعيين المقاصد وقواعد تحقيقها.

ومع التسليم بمقاصدية المصلحة في النظام القانوبي، فبإن الإشكال الذي يطرح هو

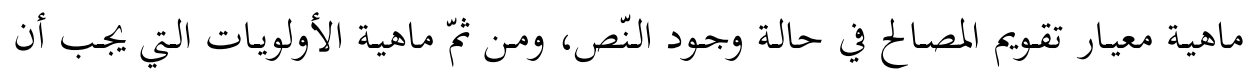

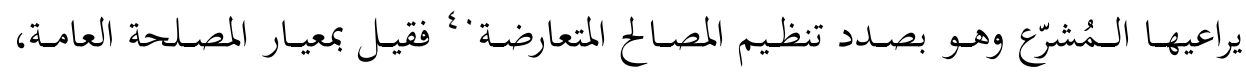
فكلما كانت المصلحة الفردية أقرب إلى المصلحة العامـة كانت هي التي هلها الأولوية في

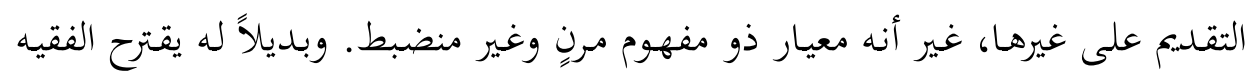

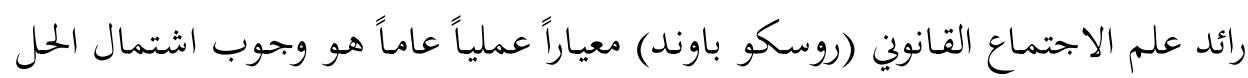

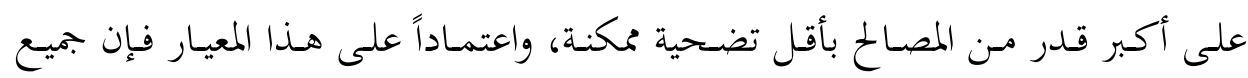

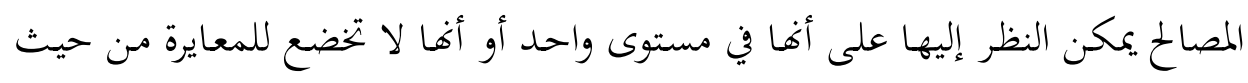
ترتيب الأهمية. اء غير أن هذا المعيار بدوره غير ممكن التطبيق؛ لأن وضع الحقوق والمصالح

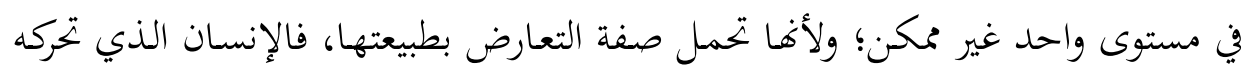

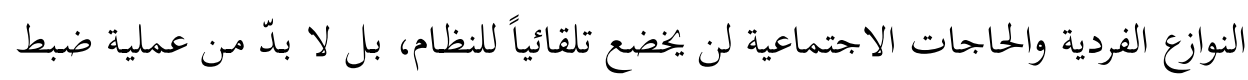

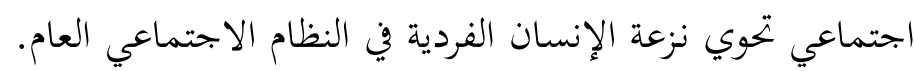

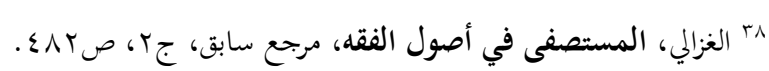

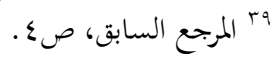

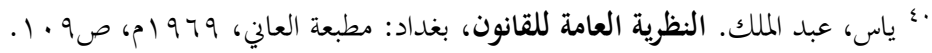

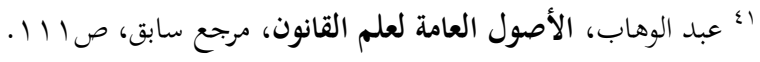


وعليه، فإنه بالرغم من اشتراك مقاصد الشريعة ومقاصد القانون في استهداف تحقيق

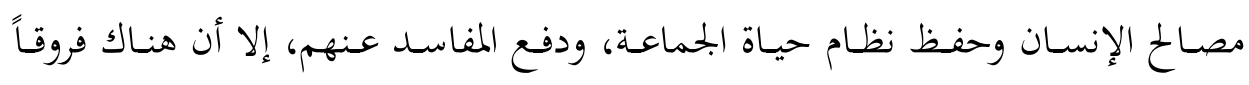

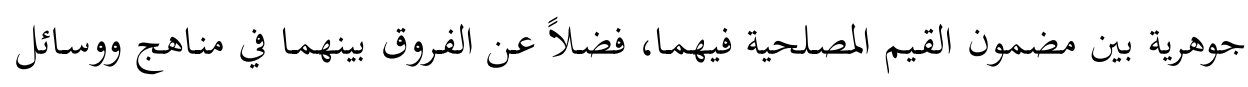

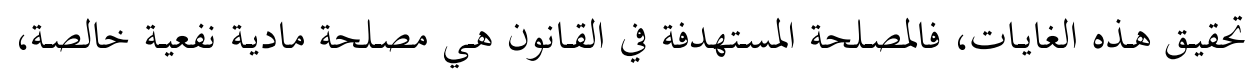

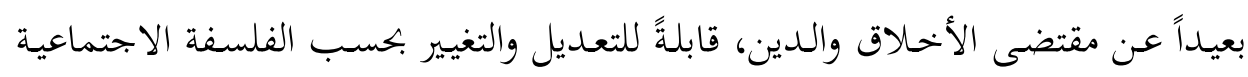

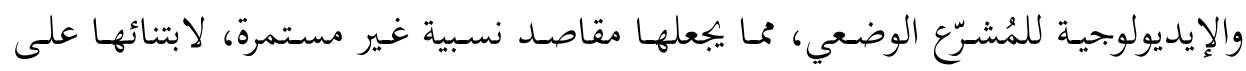

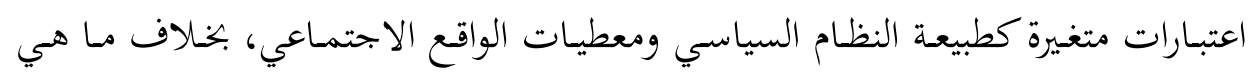

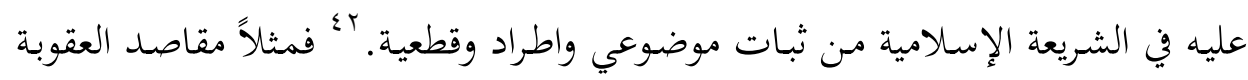
الحدّية في الشريعة ثابتة وقطعية في تحقيق مقصودها في الردع العام والخاص، وفئ وفقاً للمعيار

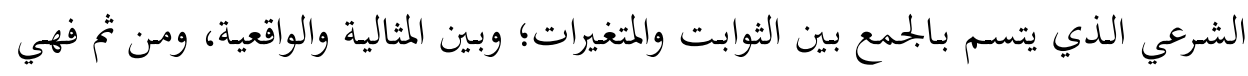

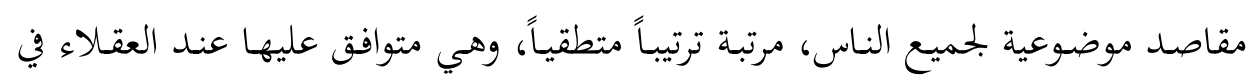

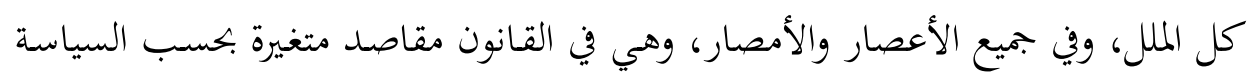
العقابية المنتهجة في الدولة وفقاً للمعيار الإنساني.

\section{رابعاً: استثمار مقاصد الثريعة في صياغة أهداف القانون الوضعي}

سبق البرهنة على معيارية التشريع الوضعي وضروريتها، لتنظيم الحياة الاجتماعية

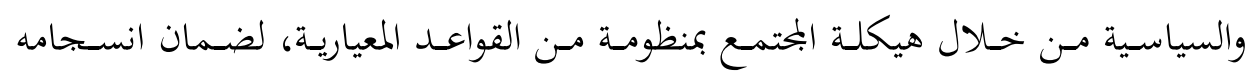

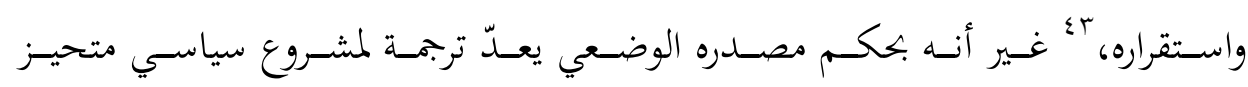

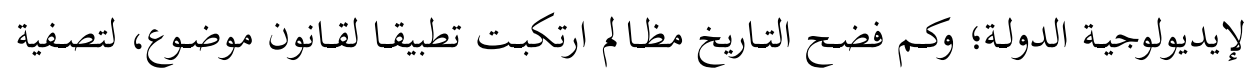

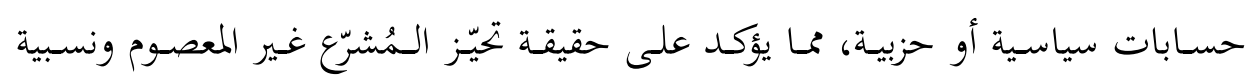

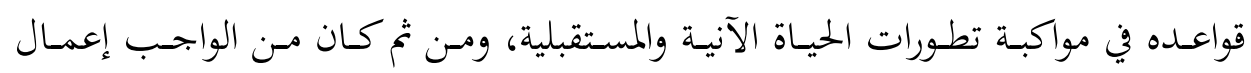

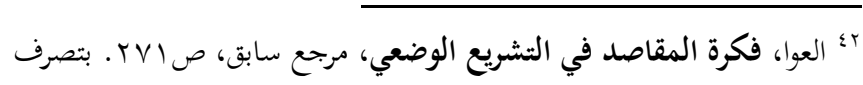

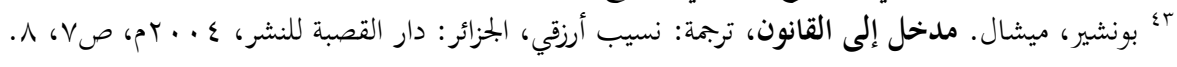




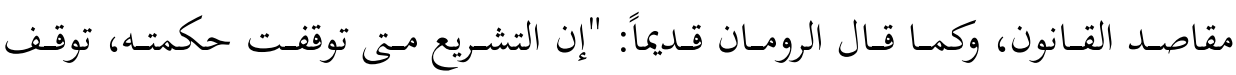
حكمهد.

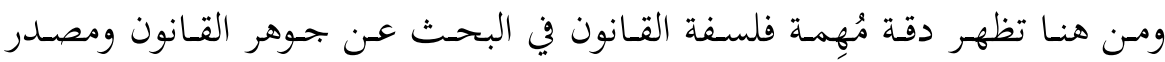

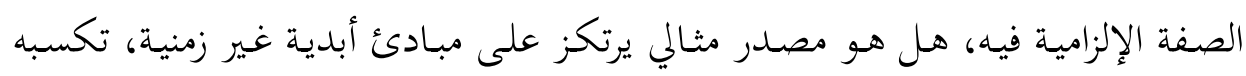

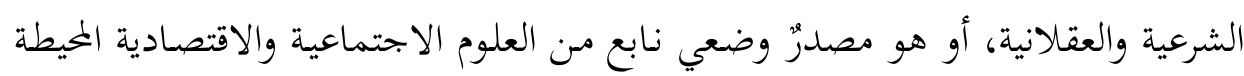

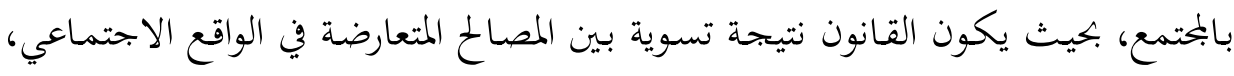

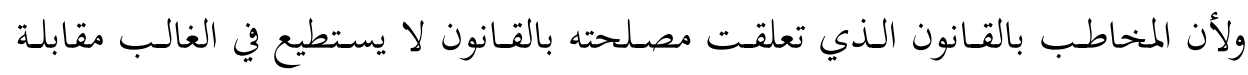

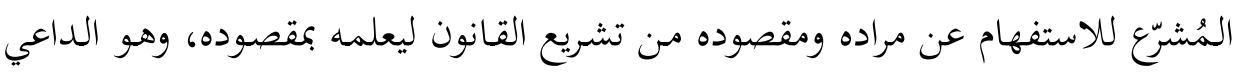

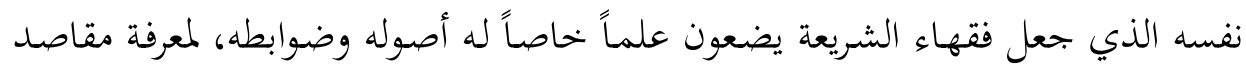

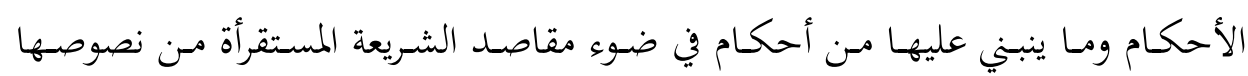
وأحوالها استقراءً قطعياً.

وترتيباً على ذلك، فإن عدم مراعاة فلسفة القانون في فهم التشريع الوضعي سيؤدي

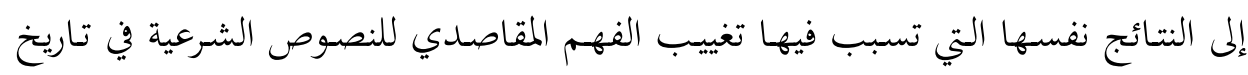

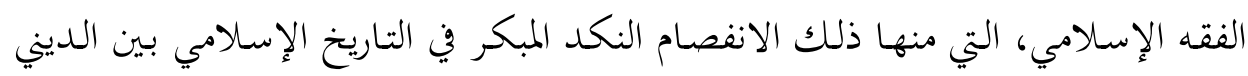

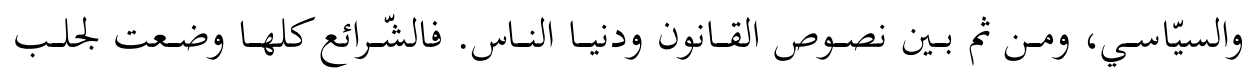

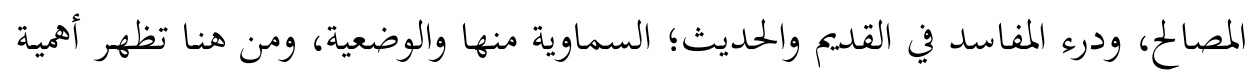

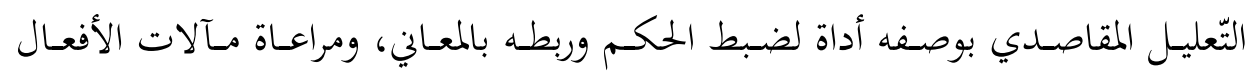

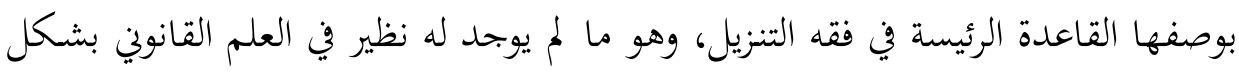

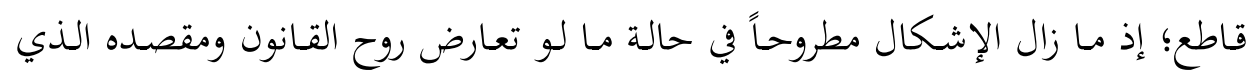

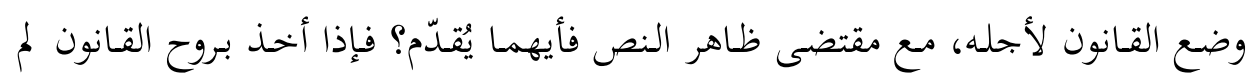

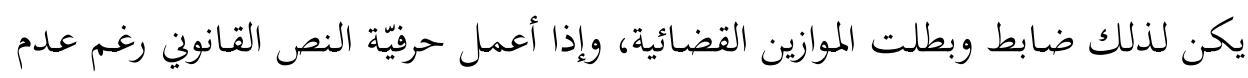

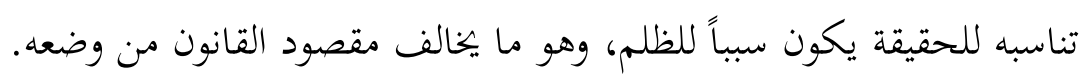

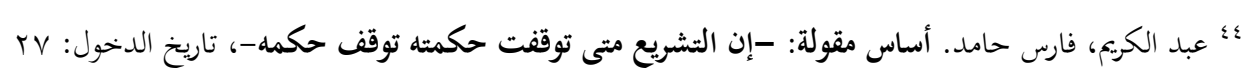

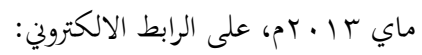

- http://www.babil-nl.org/b02x036fh.htm 
ولقد أثبتت التجارب العالمية أنه مهما تحرّت النصوص القانونية المصلحة، فإنها تبقى

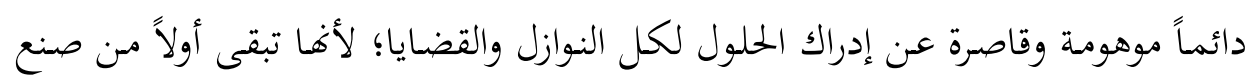
البشر غير المعصوم، ولأها تتناهى بوصف عددها، بخلاف الوقائع التي لا تتناهى، فيبقى الملاذ هو القضاء لإعمال اجتهاده الخلالّق في إيجاد حلول لها. ومن هنا تطورت ابحاهات تفسير القـانون بتطورات الحيـاة الاجتماعيـة المعاصرة والمتسـارعة، التي لم يعـد باستطاعة المُشُرّع بحاراهـا بحركته الثقيلة المعهودة، مما تطلب وجود عقليـة قضائية فذة تلائمم بين النص والواقع، تسد القصور التشريعي، ومسن ثم ينتظر من توظيف مقاصد القانون إزالة

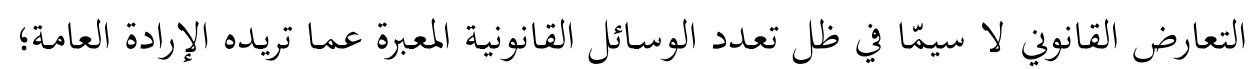

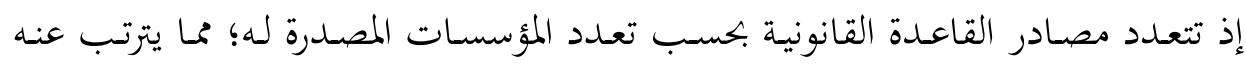
احتمالية وقوع التعارض بين هذه القواعد، وهذا يهدد مبدأ الأمن القانوني بوصفه هـفاً عاماً للقانون، وعندها يكون من أهم مهام القاضي الحفـاظ على وحسدة النظام القانولي

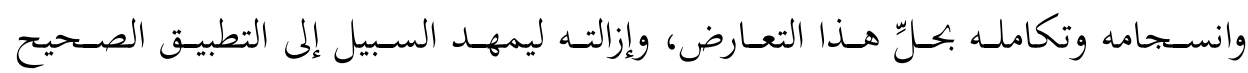

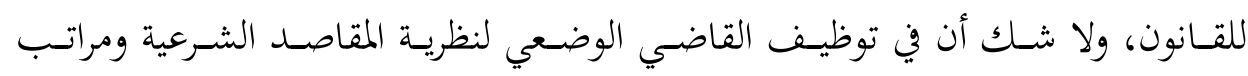
المصالح فيها، دخل في حلّ التعارض بين قواعد النظام القانوني الواحد وفقاً لمنهج مقاصد

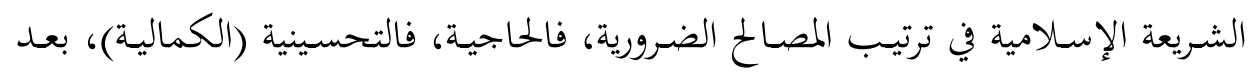

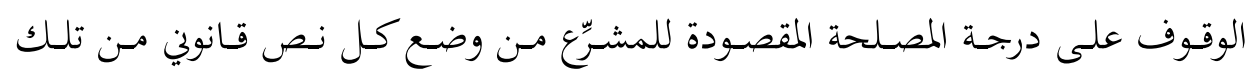
النصوص المتعارضة.

\section{I ـ مقاصد التشريع الوضعي لدى فلاسفة القانون:}

من العلوم القانونية القريبة من علم مقاصد الشريعة والموازية له علم فلسفة القانون،

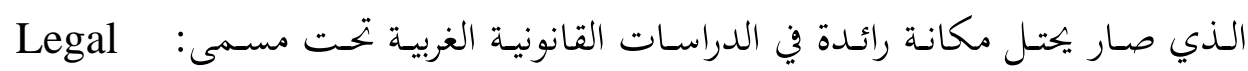
ophilosophy التي تكمن وراء النُّم القانونية، والكشف عن العلاقة بين القانون والبحتمع، وهي عموماً

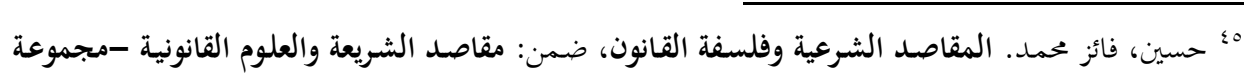

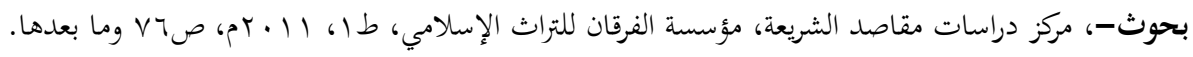


تدور حول: حماية حقوق الإنسان، وتحقيق العدالة والصالح العام؛ والاستقرار القانوين والأمن القانوني.

ويحاول هذا العلم المساعد في النظم القانونية التوفيق بين الغايات السابقة بنسب

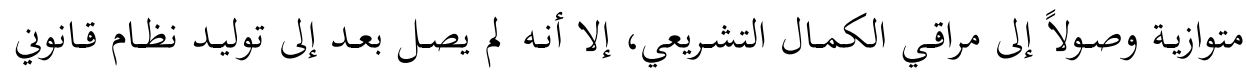

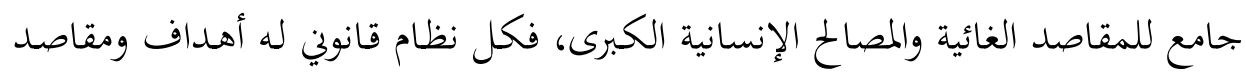

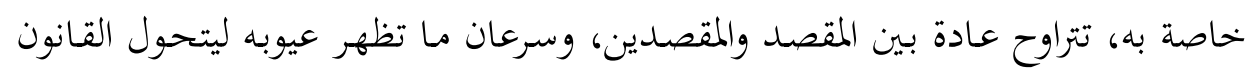

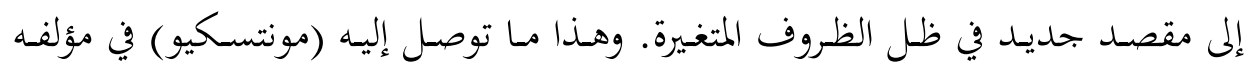

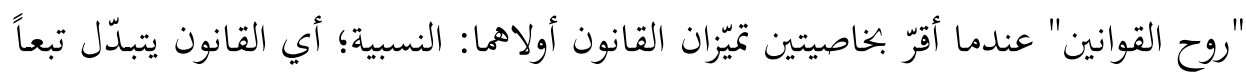

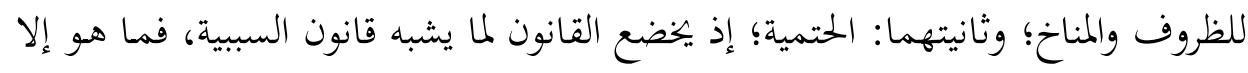

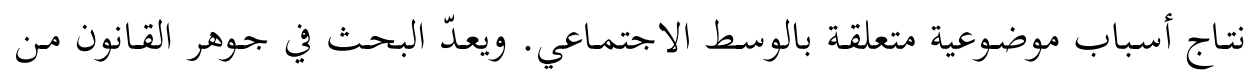

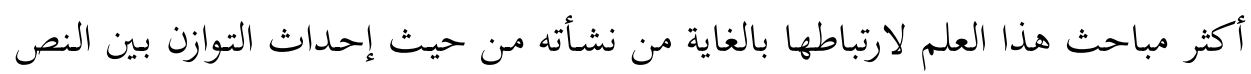

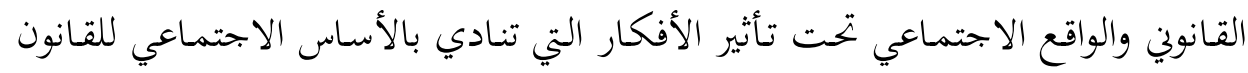

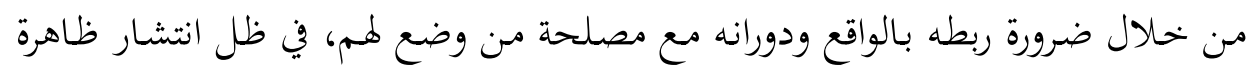

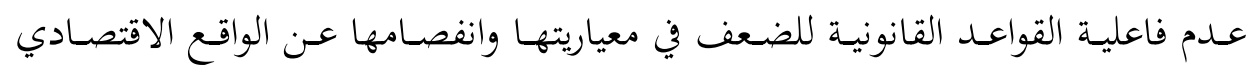

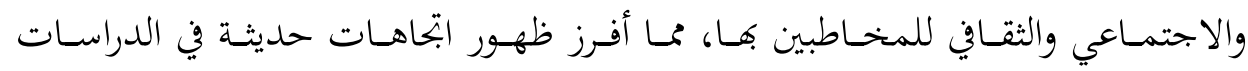

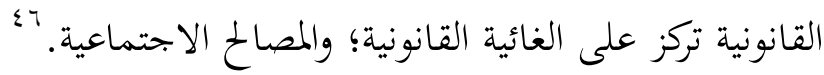
وبناء عليه يظهر الربط بين علم فلسفة القانون وعلم المقاصد الشرعية لاشتراكهما

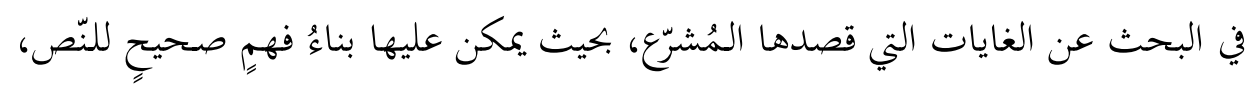

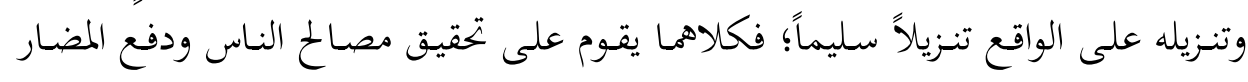

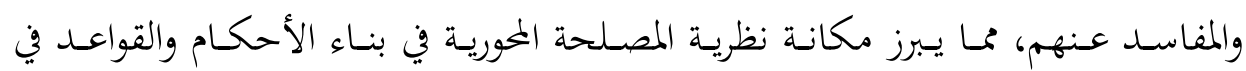

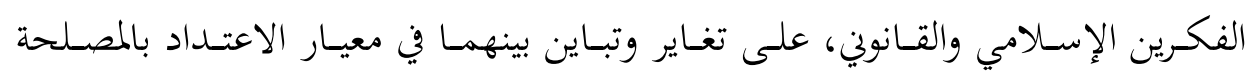

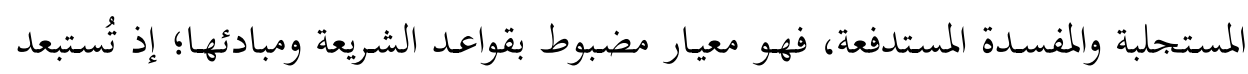

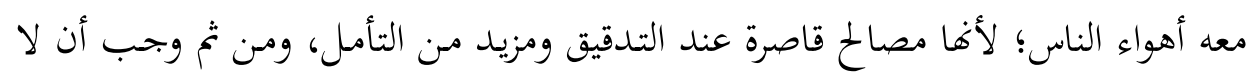


تخالف مقاصد الناس مقاصد الشارع الحكيم، فالمصالح المعتبرة هي التي قام الدليل على اعتبارها، وهي بعد الاستقراء والتحقيق تشمل بحموعة المصالح التي تتوقف عليها حياة

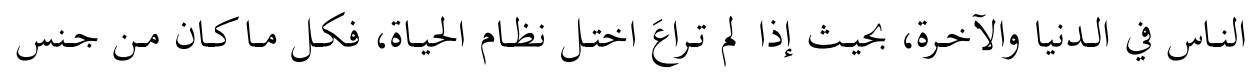
ذلك فهو مصلحة، وكل ما يفوته فهو مفسدة.

\section{Y. ب تطور مقاصد القانون في الفكر القانوني الوضعي:}

خطـت فلسـفة القـانون أشـواطاً في المزاوجــة بـين تعـاليم الـدين القـويم ونتـاج العقـل السليم، وساهمت في دفع عجلة الحضارة الغربية بصورة غير مسبوقة، لا سيما في الدول

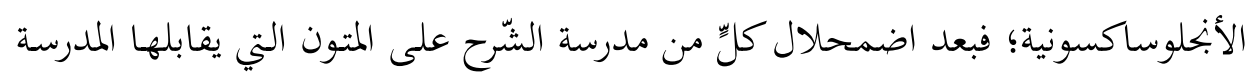
الظاهرية في الفقه الإسلامي، والمدرسة التاريخية لإغفالهما مراعاة حكمة القانون ومقاصدي ملاصده في فهم النص وتنزيله؛ إذ المنطق يقتضي تنزيه أفعال العقلاء عن العبث، ومن ثم تمكون لكل قـانون غايـة وحكمة مقصودة مـن تشريعه تُعرف مـن خهلال الاسترشـاد بالأعمال

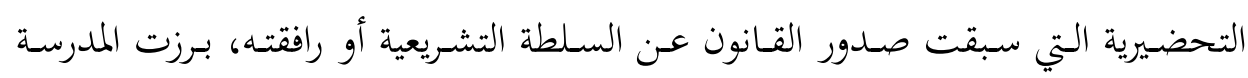

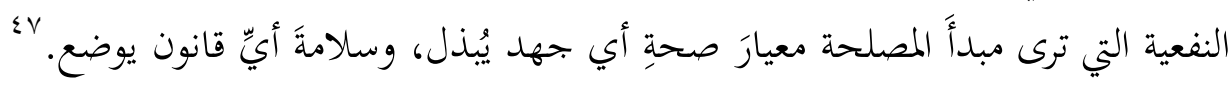
وعلى الرغم من عدم وجود نظرية خالصة لمقاصد القانون الوضعي، إلا أن الباحث

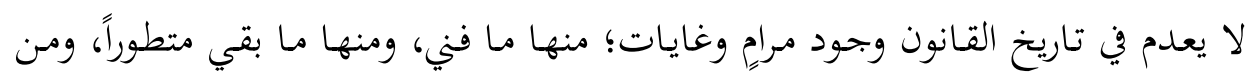

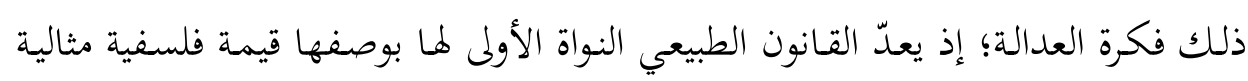

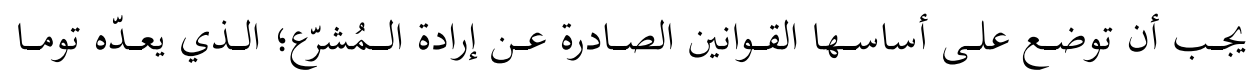

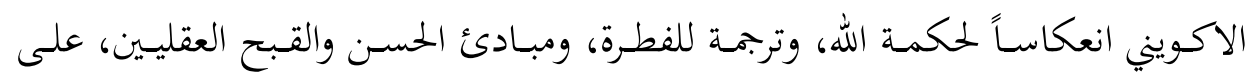
أساس أن مبادئ القانون الطبيعي هي مبادئ ثابتة يدركها ويشعر بها كل عقل إنساني،

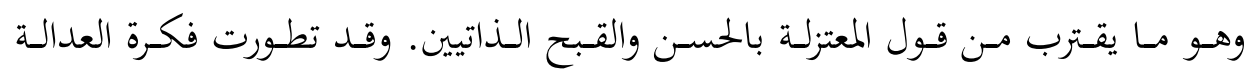

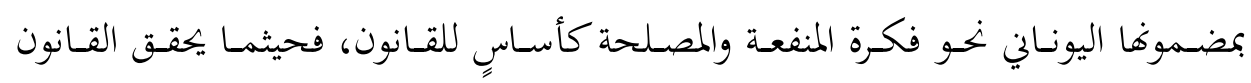

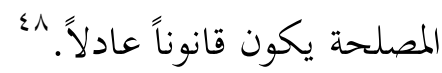

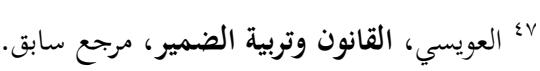

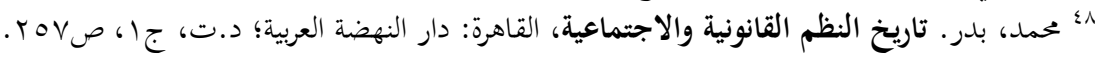




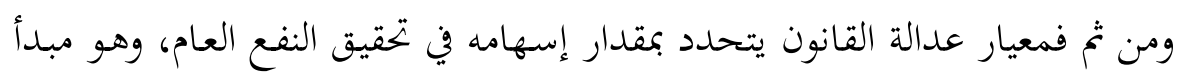

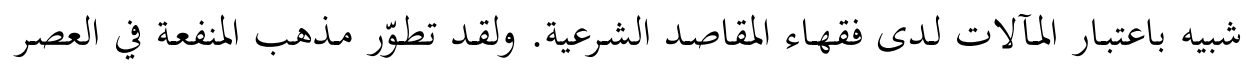

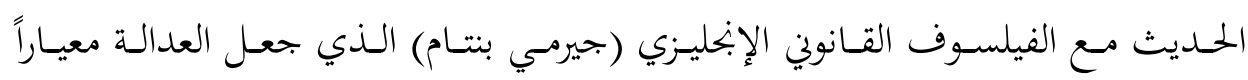

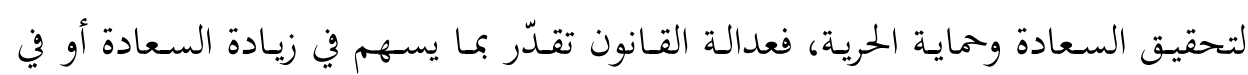
التقليل من شقاء الإنسان.

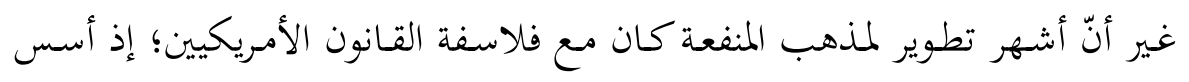

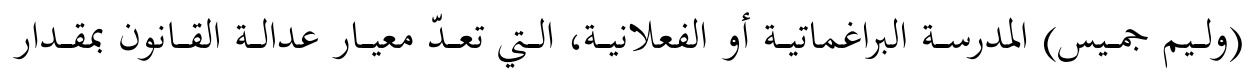

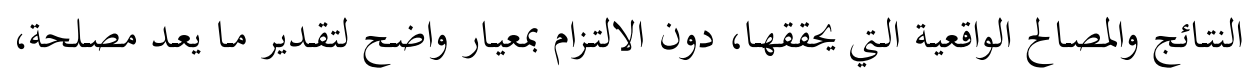

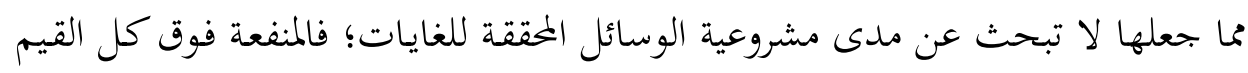

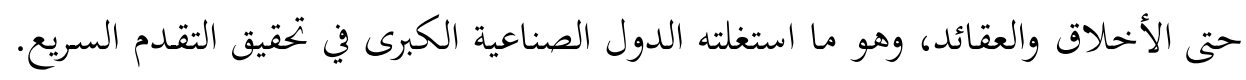

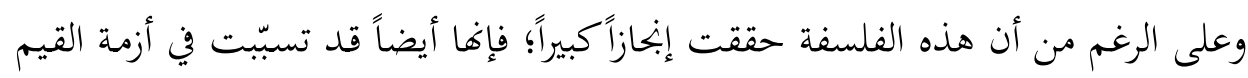

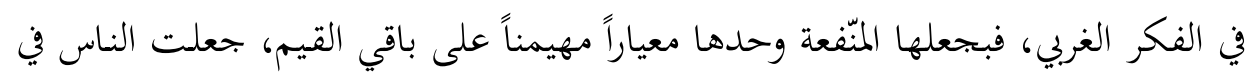

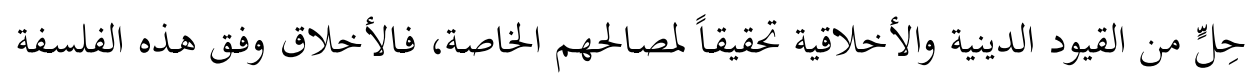

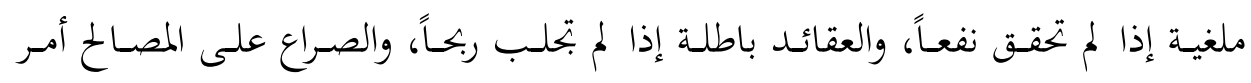

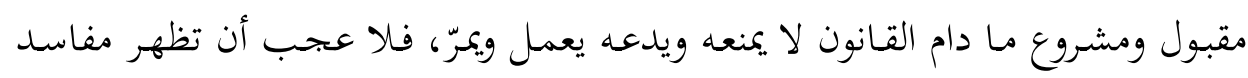

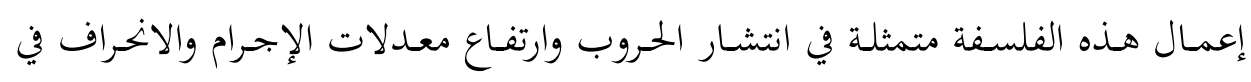

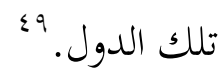
وجدير بالإشارة أن فكرة العدالة بصفتها مقصداً غائياً لإقامة التوازن بين مصلحة

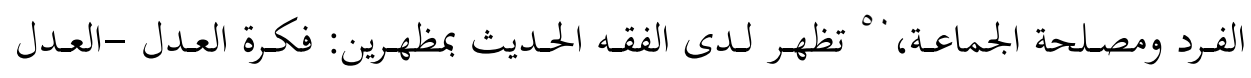

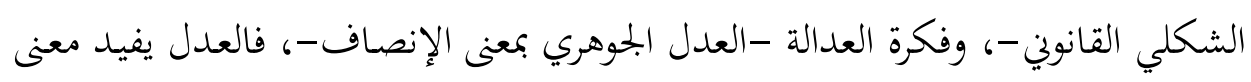

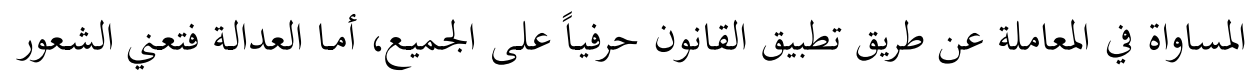

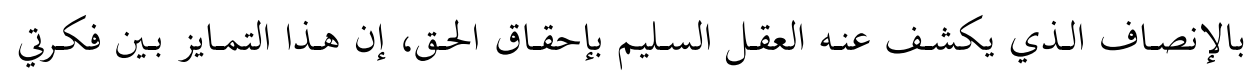

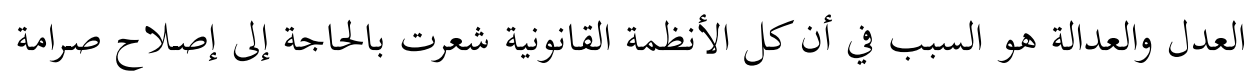

9؛ جيوانتو، سمو المقاصد الشرعية بين الفلسفة النفعية والدور الرسالي ومقام العبودية، مرجع سابق.

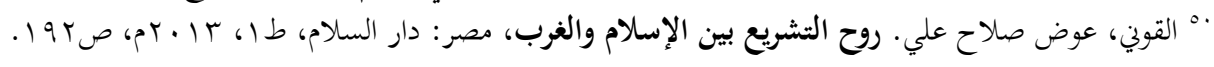


القـانون مـن خهلال الدعوة إلى تفسير القـانون بروح العدالة بـلـلاً مـن التركيز على حرفيـة

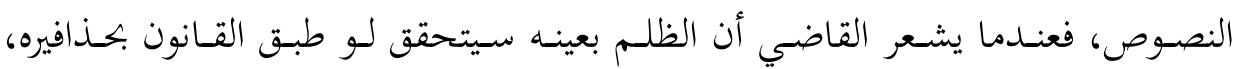

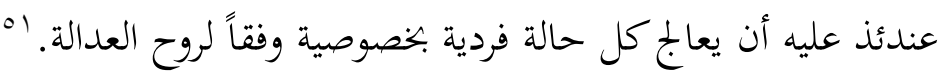
وقـد ظهرت عـدة دراسـات تؤصل للفلسفة المصلحية للقـانون، ففي ألمانيـا ظهرت

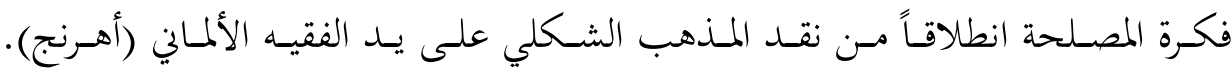

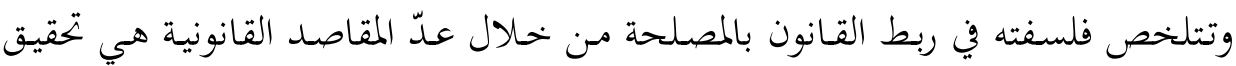

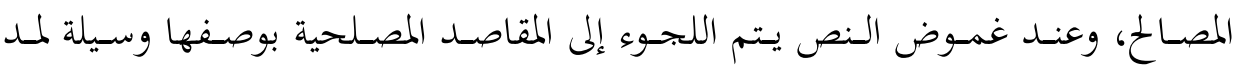

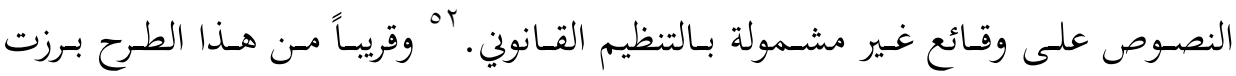
المدرسة الوضعية النفعية الإبحليزية التي قامت على وفير نقد المذهـب الطبيعي، مستبعدةً فكرة

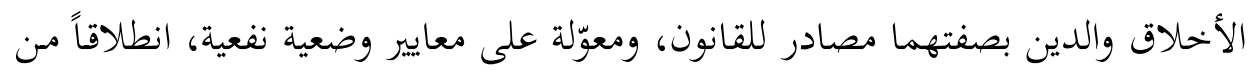
مدى تحقيق المنافع والملذات ودفع المضار والأذى، ومن ثتم فليس العدل مقصداً في حد

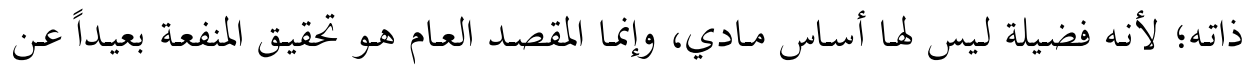
القيم الأخلاقية والدينية، وعلى هذا يكون المقصد الوحيد للقانون وللدولة هو تحقيق أكبر قدر ممكن من النفع للأفراد، ودفع أكبر ضرر مادي عنهم، ليرتبط القانون بالمنفعة وجوداً

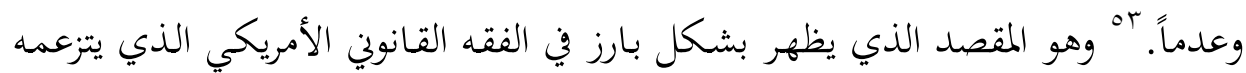

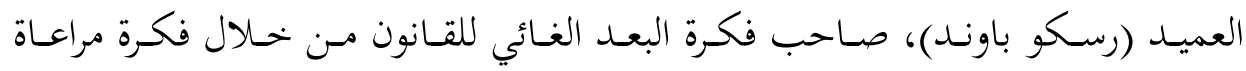
المصلحة الاجتماعية التي يعدّها أساس القانون؛ وهي الفكرة التي ترسبت عند (بأند (باوند) تحت تأثير الأفكار الاجتماعية، فضلاً عن ملاحظته للعيوب الجسيمة التي شابت القضاء الأمريكي الذي يعتمـد على أسلوب السوابق القضائية؛ إذ وصفه بالقضـاء الميكانيكي

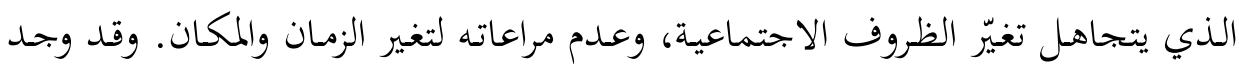

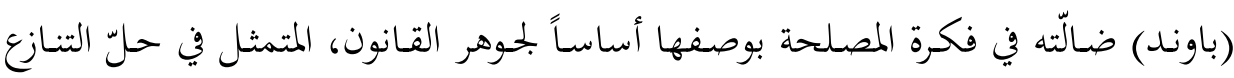

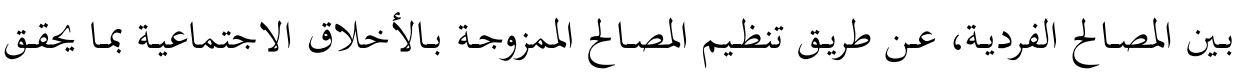
اo عبد الكريع، فارس حامد. القانون والسلم الاجتماعي، على الرابط: - http://al-nnas.com/ARTICLE/FHAbdkrem/14pc.htm

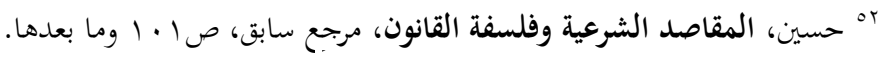

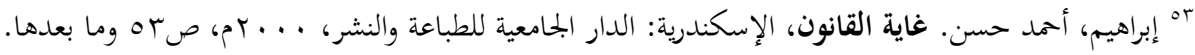




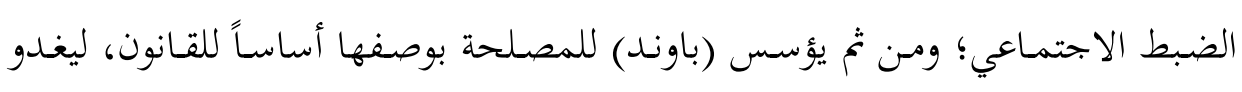
بذلك القانون عند (باوند) هو علم الهندسة الاجتماعية الذي يتحقق من خلاله تنظيم

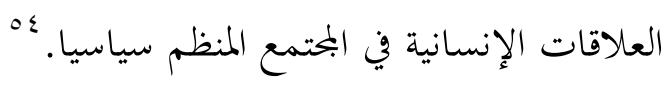

وتعتمد المدرسة النفعية على المنطق التجريبي بأن يقاس القانون على أساس نتائجه

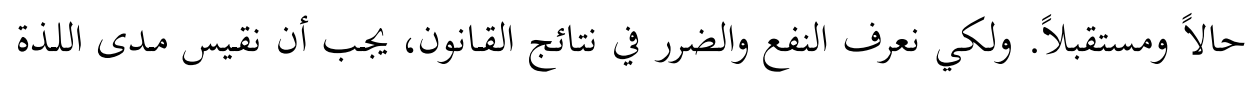

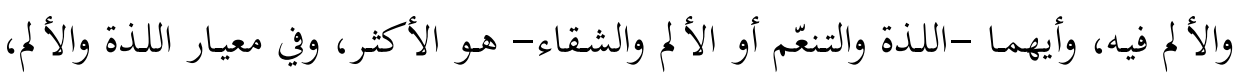

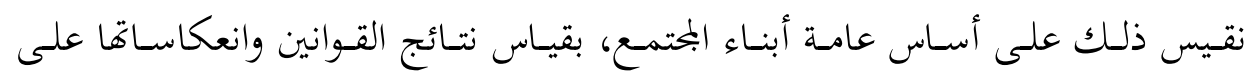
أوضاع الناس، ومدى مساهتها في خيرهم وصلاح معاشهم، فاللذة هي مقياس السعادة.

\section{خامساً: مظاهر الاستثمار المقاصدي في أفرع التشريع الوضعي}

تمخضـت الجهـود الفكريـة السـابقة عـن استواء مقاصـد القـانون وابتناهـا على نظريـة

المنفعة؛ إذ تصبح الغاية من وضع القانون هي تحقيق المصلحة بوصفها معياراً لمدى عدالة

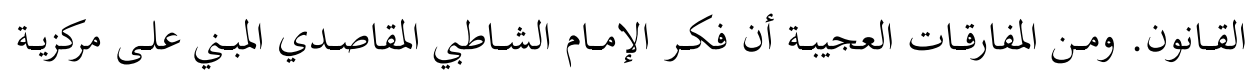

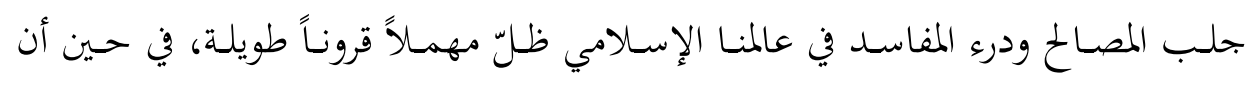
الفلسفة النفعية حظيت بالعناية والترويج في العالم الغربي.

ولا شك في أن نقد فلاسفة القانون الصارم للمدرسة التاريخية وأنصار حرفية النص

ومدرسة الشرح على المتون في محاولتهم للبحث عن روح القانون، أعطى للعلوم القانونية

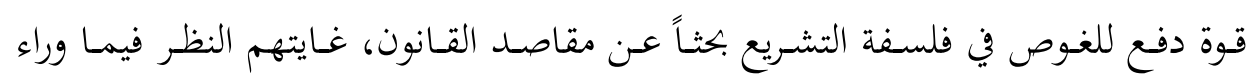

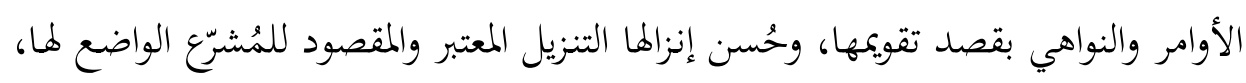

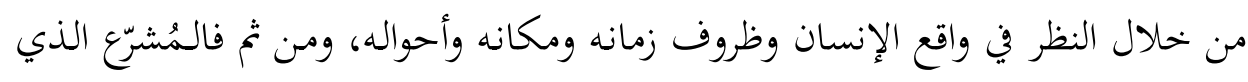
لا يحرص على تحقيق المصالح ودرء المفاسد، ولا على ضرورة مطابقة القوانين التي يصدرها للنصوص الدستورية المعبّرة عن الإرادة العامة، لا يستطيع الاستمرار ولا يحقق الاستقرار. 
وعليه يكون المقصد الأساسي للقانون هو الحفاظ على المصالح من خحلال التوفيق

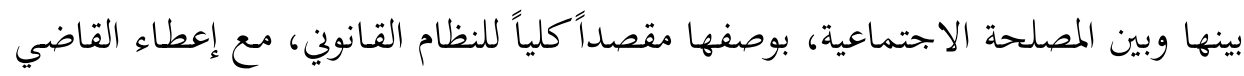
دوراً فاعلاً في دراسة كل حالة وظروفها الواقعية.

وفضلاً على مقصد العدالة والمصلحة لا نَعْدَمُ مقاصد أخـرى متضـمنة داخـل كل

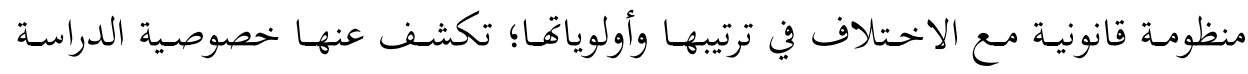
التفصيلية لكل فرع من أفرع القانون المنظّمة لمختلف العلاقات الاجتماعية.

\section{1 ـ تطبيقات على مراعاة نظرية المقاصد في العلوم القانونية الحديثة:}

لا شك في أن القانون الوضعي هو الذي يحكم اليوم معظم مناطق العالم بدساتيره

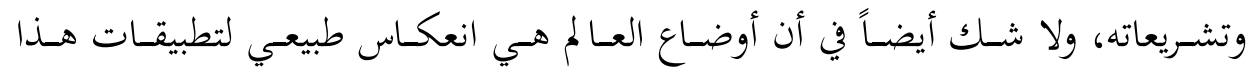

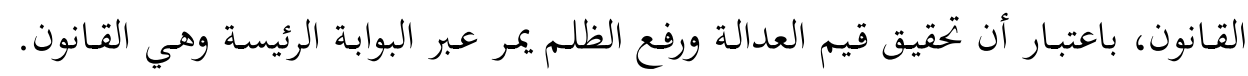

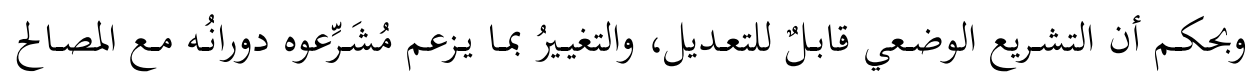

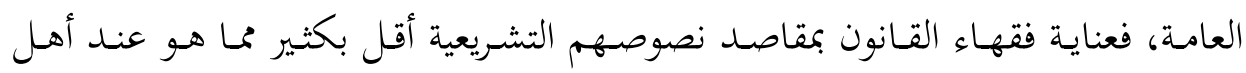

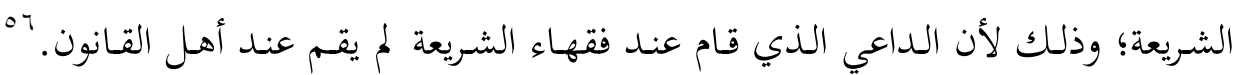

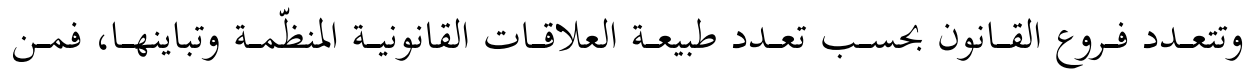

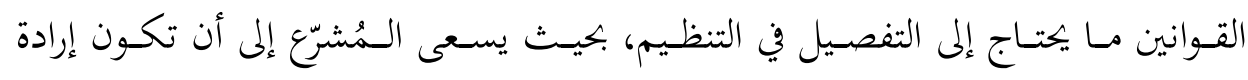

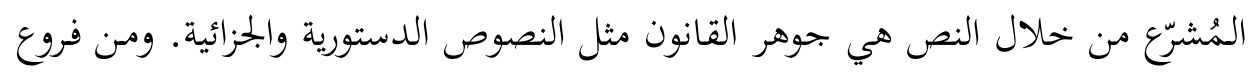

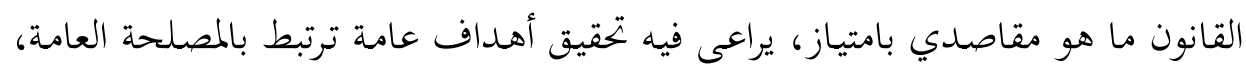

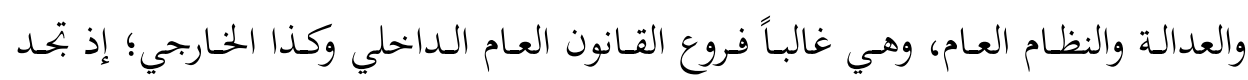

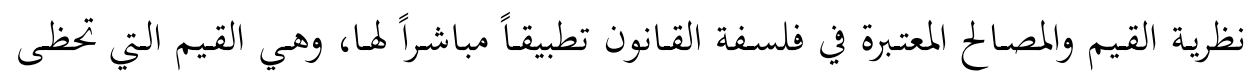

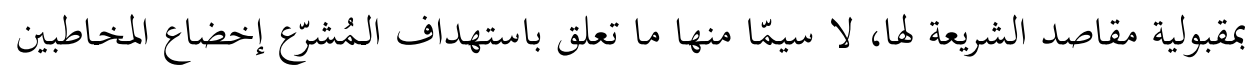

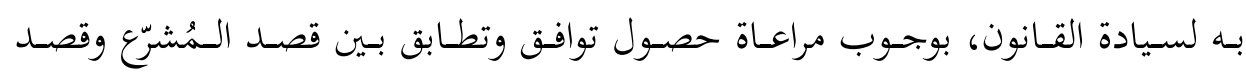

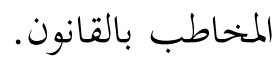

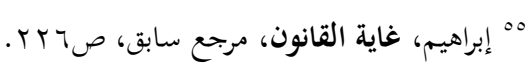

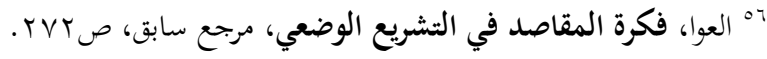




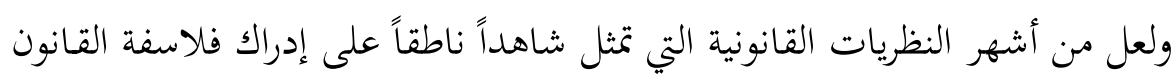

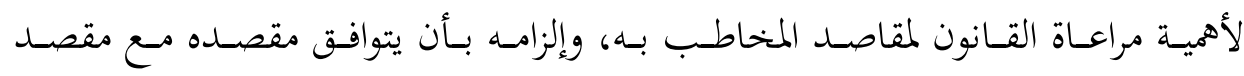

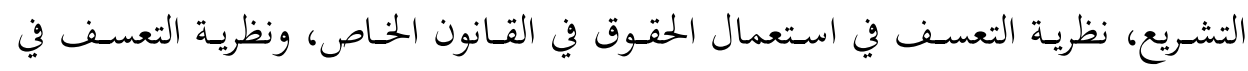

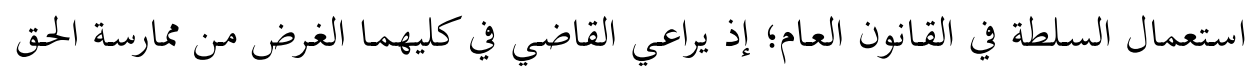

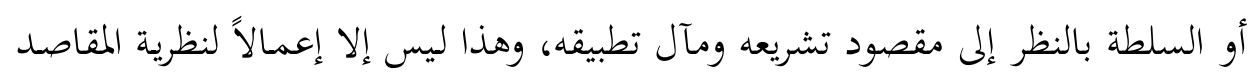

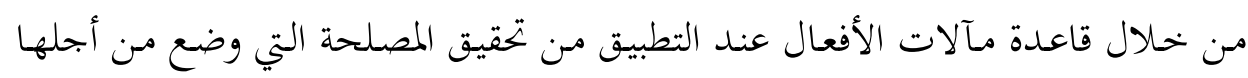

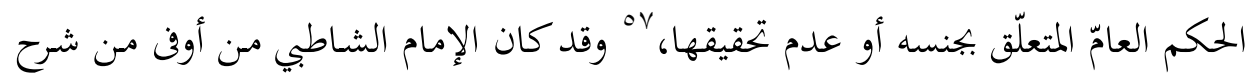

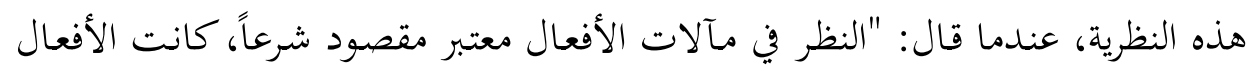

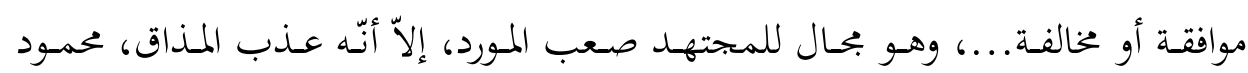

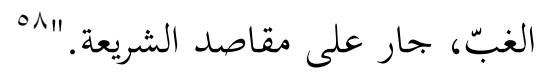

ويترتب على ذلك أن تطبيق الحكم الشرعي على الأفعال ينبغي أن يكون ملحوظاً

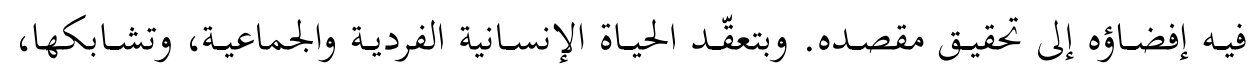

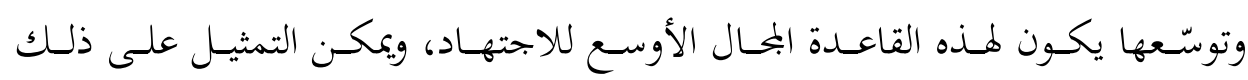

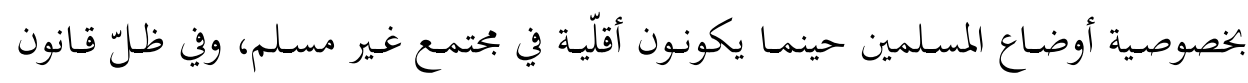

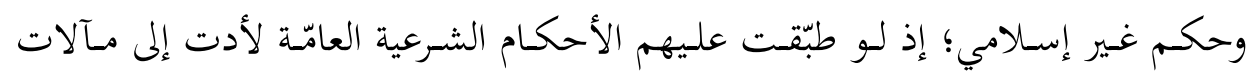

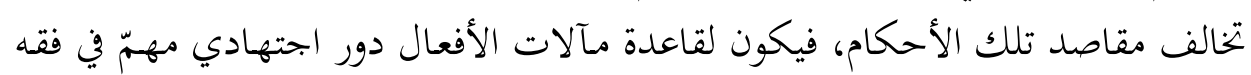
الأقلّيات المسلمة.

وعليه فقد أثمر توظيف نظرية المقاصد في فلسفة التشريع إنتاج عدد مـ النظريات

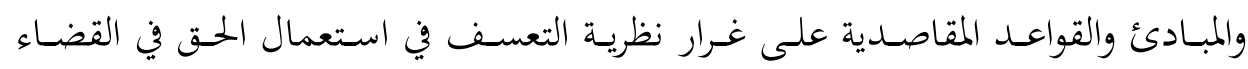

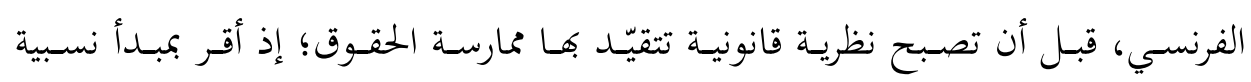

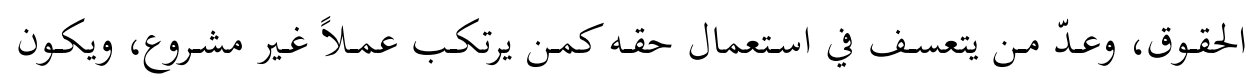

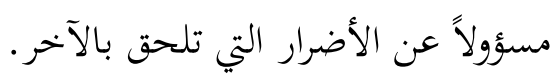

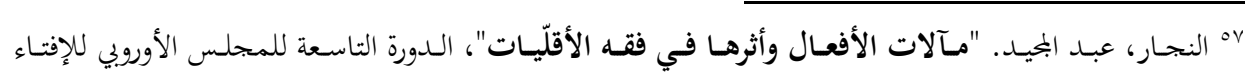

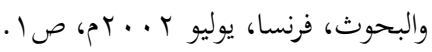

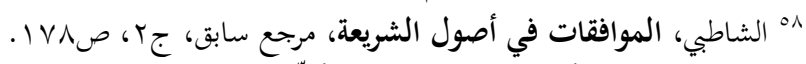

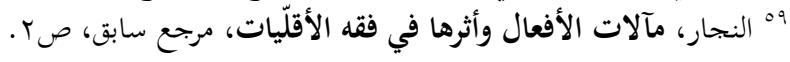


كما أثمر توظيف المقاصد في فلسفة القانون إنتاج قوانين وتشريعات ضبطية، تراعي

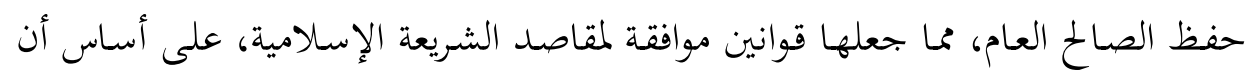

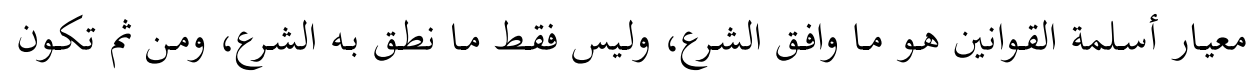

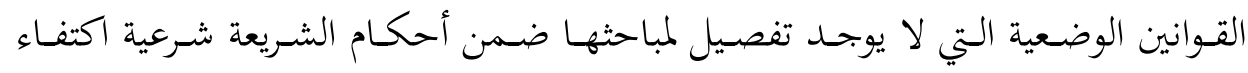

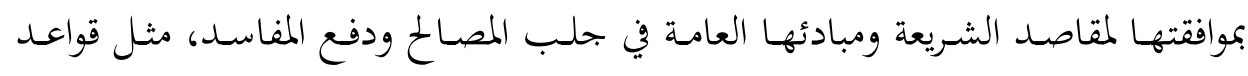

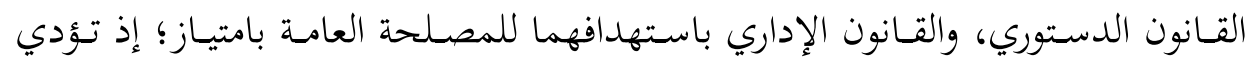

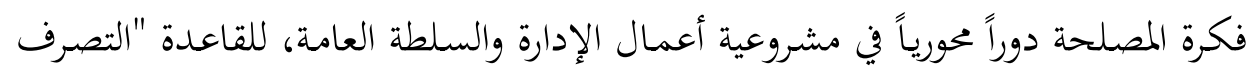
على الرعية منوط بالمصلحة"، التي صارت تمثل أحد مفاصل فلسفة القانون التي تطلّ بها على مقاصد الشريعة. . ومن أهم الأفكار المقاصدية التي جاء بها صاحب "روح القوانين" مبدأ الفصل بين

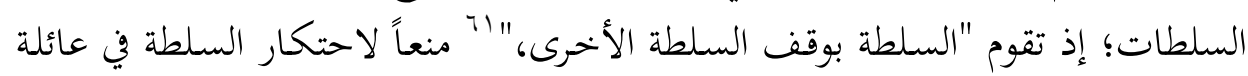
أو في حزب.

كما تظهر فكرة المقاصد المصلحية جليّة في القانون الجنائي، انطلاقاً من أن العقوبة

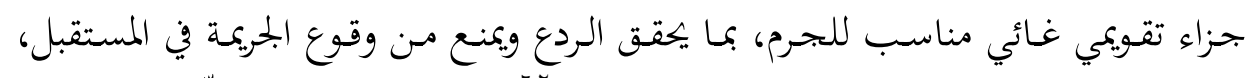

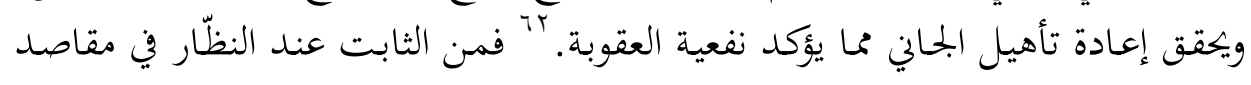

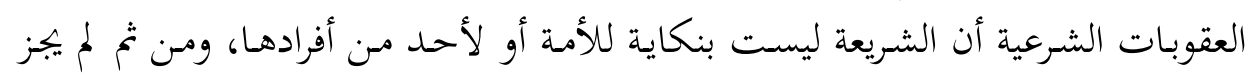

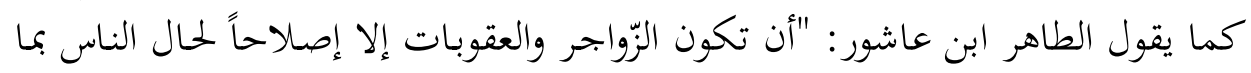

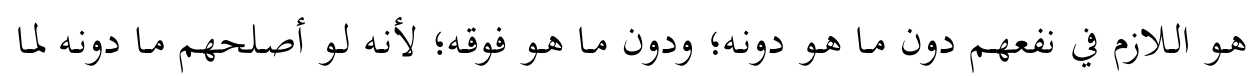

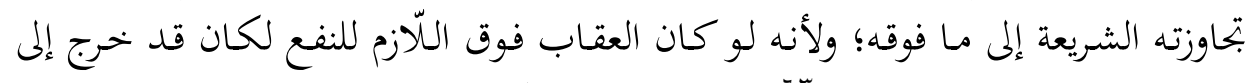

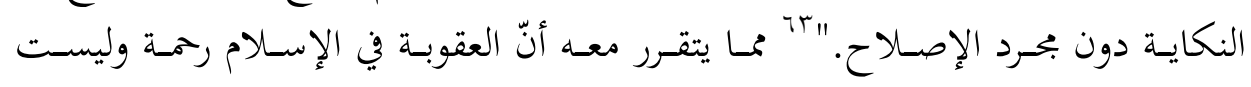

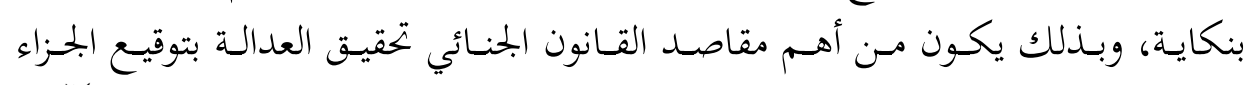

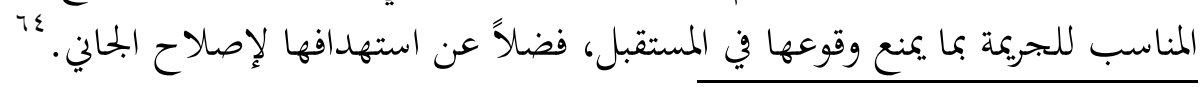

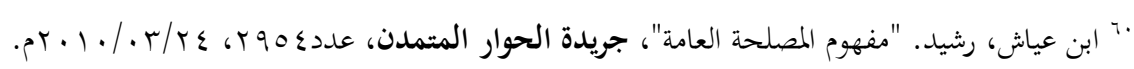

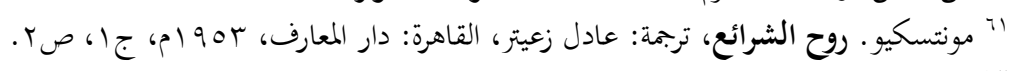

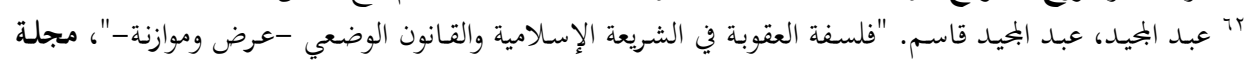

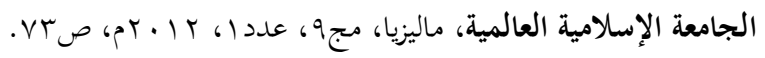

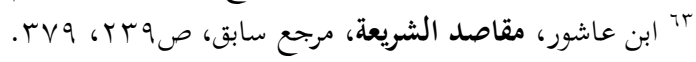

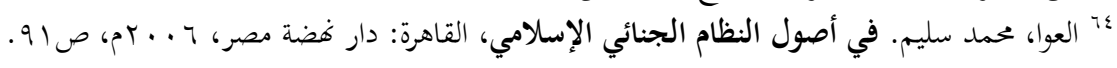




\section{Y. دور مقاصد الثريعة في توجيه مقاصد التشريعات الوضعية عقب ثورات}

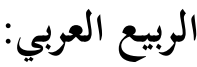

مـن أهـم إشكاليات العصـر الانفصـال النكـد بين مقـررات الشريعة وقواعـد النظـام

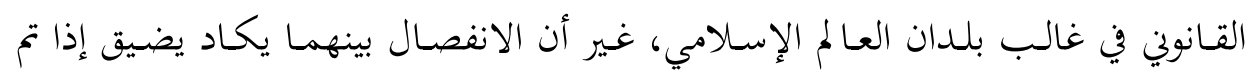

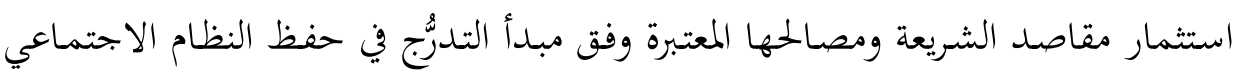

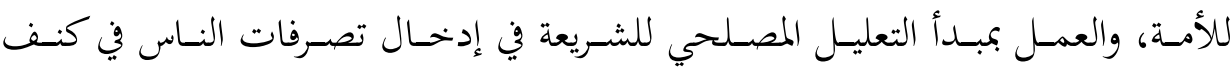

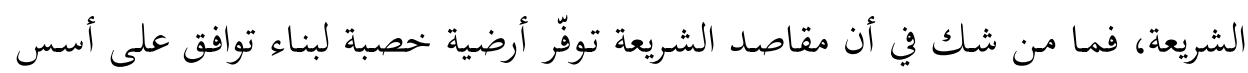
مدنية ترجح أولوية حقوق المواطنة على واجب الأسلمة. 10

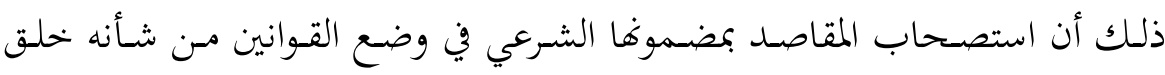

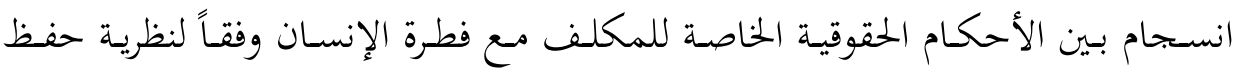

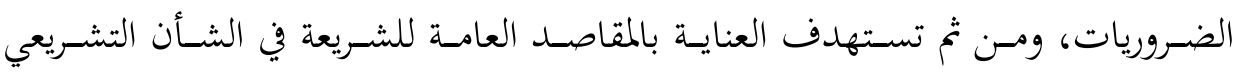

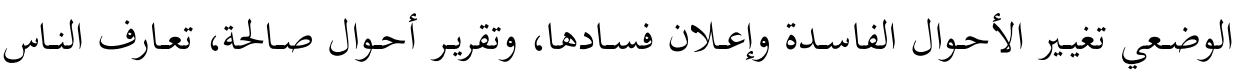

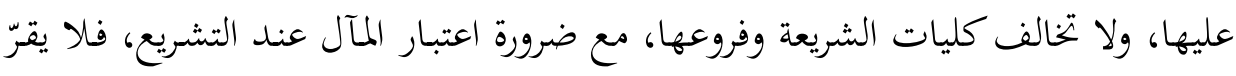

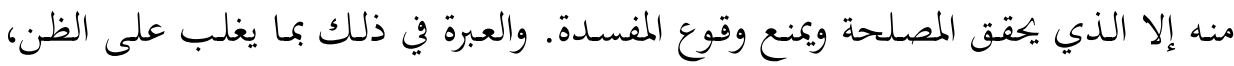

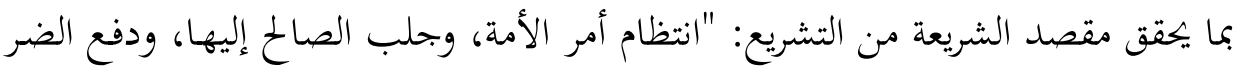

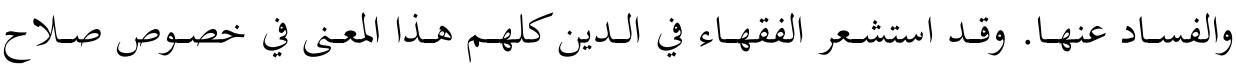

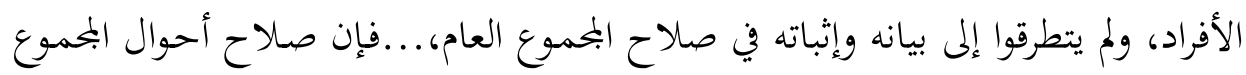

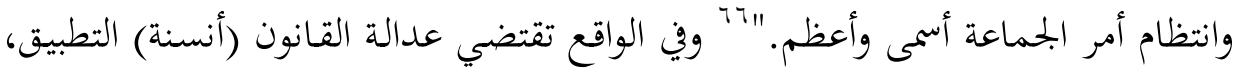

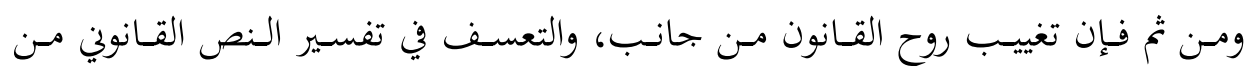

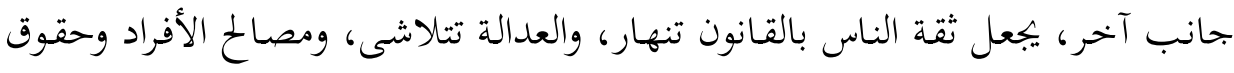
الإنسان تمدر، والإنسانية تتهاوى.

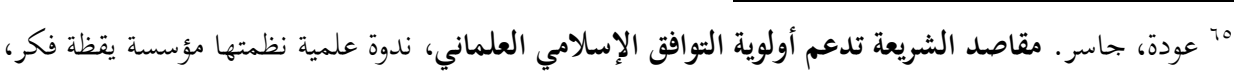

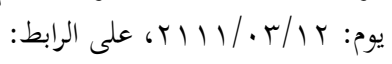

- http://www.onislam.net/arabic/madarik/culture-ideas

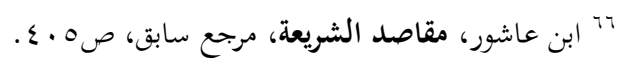

"V دعبل، الموازنة بين حرفية نص القانون وروحه مطلبّ لأنسنة القانون، مرجع سابق. 
إنّ صعود بعض التيـارات الإسلامية في المجالس التشريعية في بعض البلدان العربية، حيـث صــاعة القـانون، دفعهـم إلى البحـثث عـن البــائل الإسـلامية لبحموعـة القـوانين الوضعية، مما يجعلهم في امتحان حقيقي حول آليات قوننة الأحكام الشرعية وتنزيلها في واقع علمـاني يفصل الدين عـن الدولة والـدنيا، وهنـا يمكن ملاحظة ابتحاهين كبيرين في

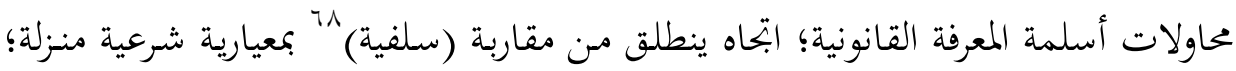

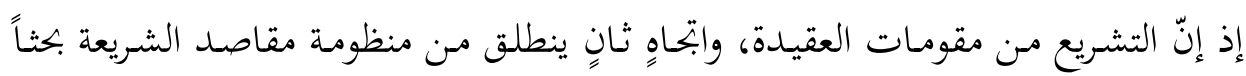
عن أرضية مشتركة مع القوانين الوضعية، مما يقتضي تضييق جوانب الخصوصية مصية التعبدية

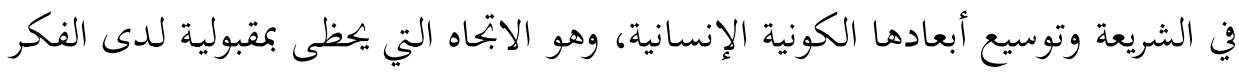

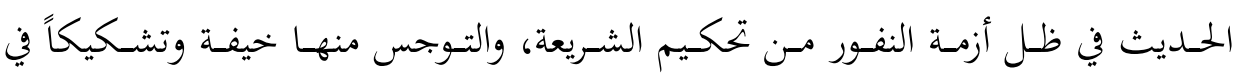
صلاحيتها، ويؤسس هذا الاتجاه خياراته على وجود اشتراك في الأسس المرجعية المعيارية للنظم القانونيـة مع مقاصـد الشريعة، إذ تعدّ نظريـة القيم وفلسفة الحـق الطبيعي الخلفيـة المرجعية لمما. 79

ويرجـع أسـاس الإشكال بـين الابتـاهين السـابقين إلى الحـلاف في المضسمون المعيـاري العيني للشريعة الإسلامية من حيث: هـل يتعلق الأمر بمدونة قانونية صارمة، أو بمنظومة الإنة

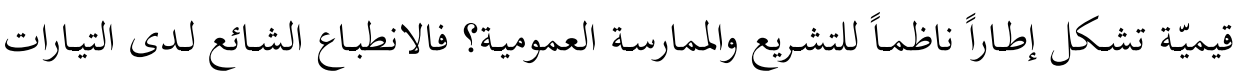
المعارضة والغربية معاً، وحتى في الأدبيات الإسلامية هو شثمولية المركزية القانونية في الإسلام لكل البحالات العمومية والفردية بما فيها أدق تفصيلات الحياة الشخصية، في حين يرى جانب مـن الفقـه المقاصـدي انطلاقاً مـن أن أحكام الإسـلام في الشـأن العـام لا تتجـاوز

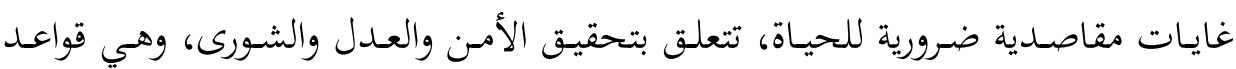

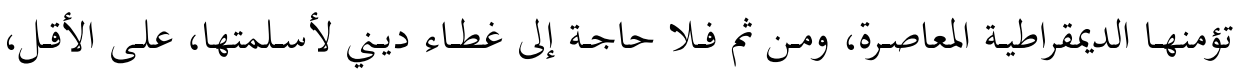

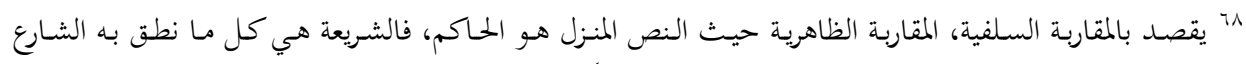

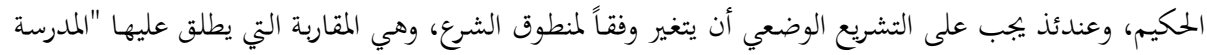

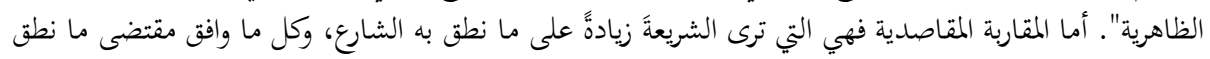

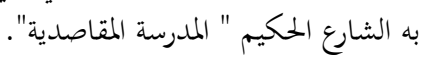

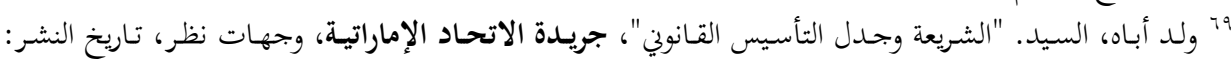

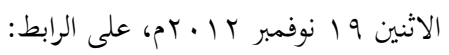

http://www.alittihad.ae/wajhatdetails.php?id=69269 
لعـدم جـدوى ذلك ظرفيـاً ومقاصـدياً، ومهن ثم كان يجـب على التيـارات الإسـلامية ترك

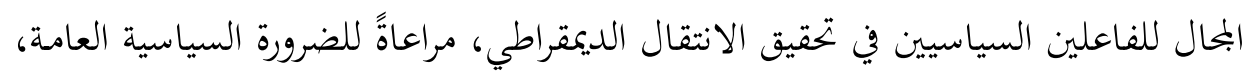
ولإكراهات الظروف الراهنة في بحربة التحول الديمقراطي في البلاد العربية، وحقائق السياق والمرحلة.

وترتيباً على ذلك يرى بعضهم مشروعية الاكتفاء بالنص على المرجعية الإسلامية في

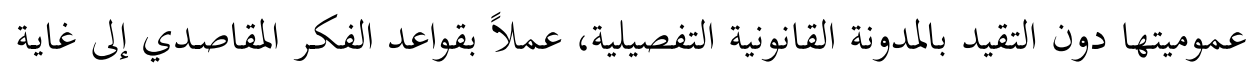

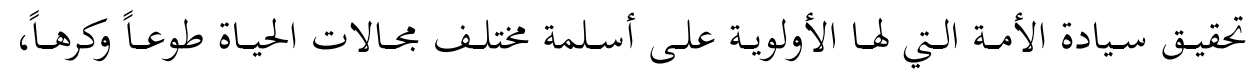

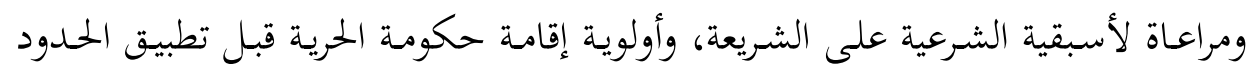

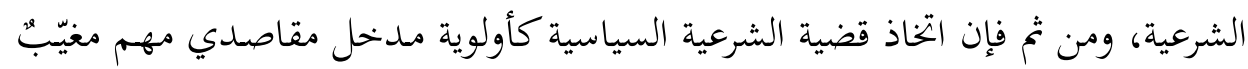

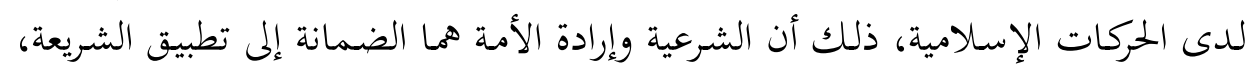

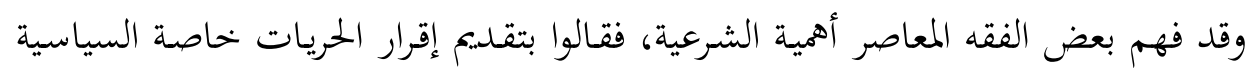

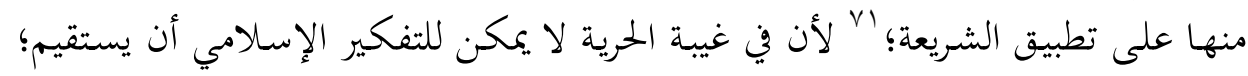

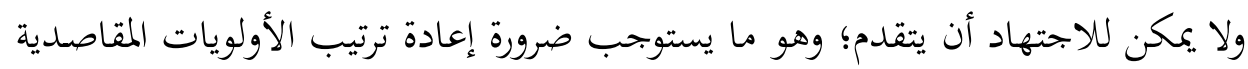
في الإصلاح السياسي والتشريعي.

ومن تخم، فإن قدرة الإسلاميين على إدارة الشأن العام والاندماج الإيجابي في المحيط

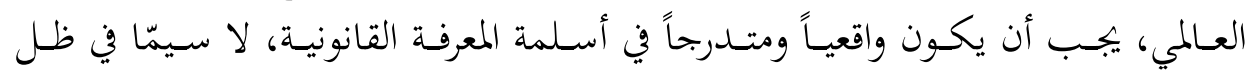

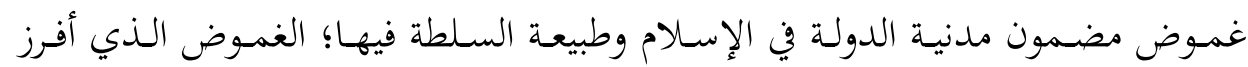

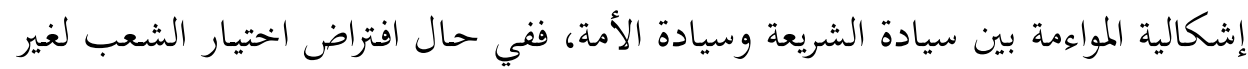

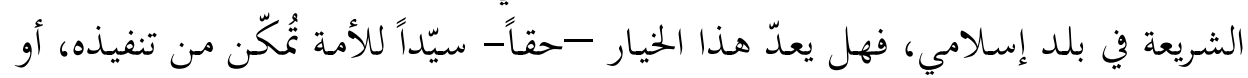

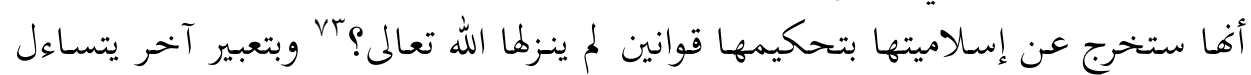

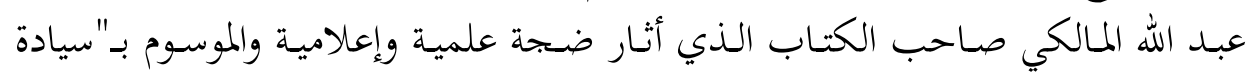

• لملد أباه، مقاصد الشريعة من منظور فلسفة القانون: الفقه ونظرية الحق الطبيعي، مرجع سابق.

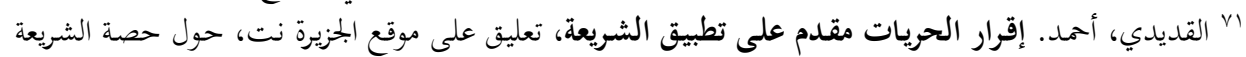

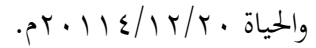

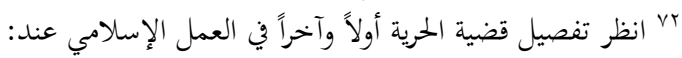

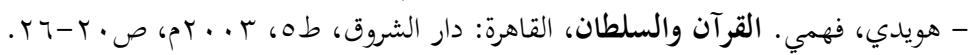

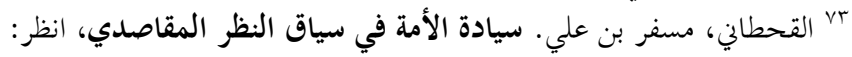

- http://www.sauress.com/alhayat/363758 


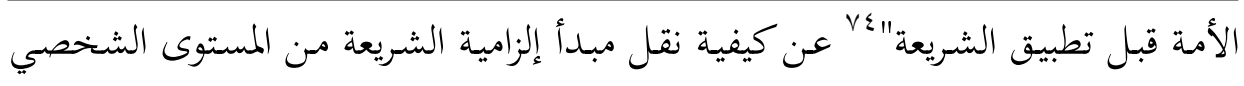

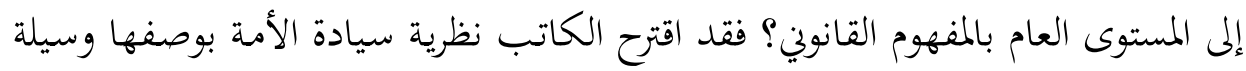

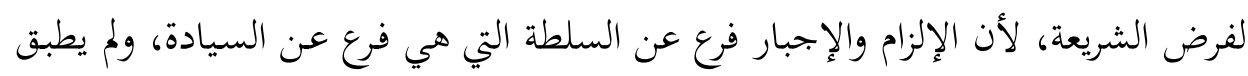

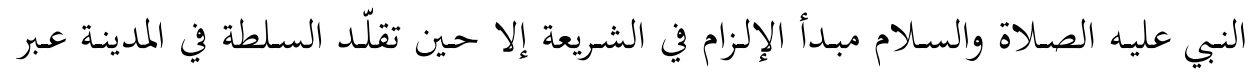

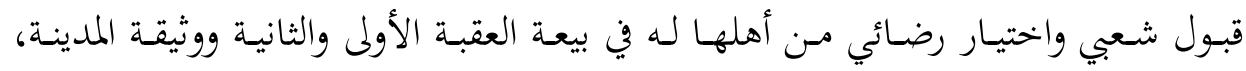

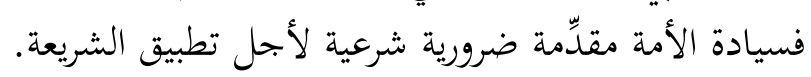

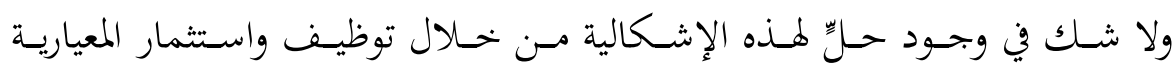

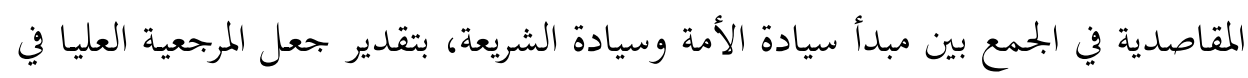

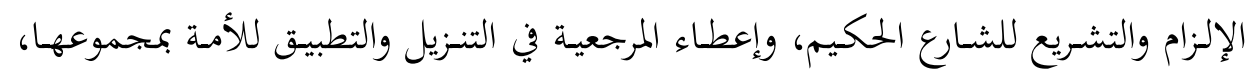

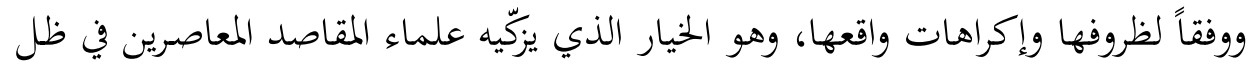

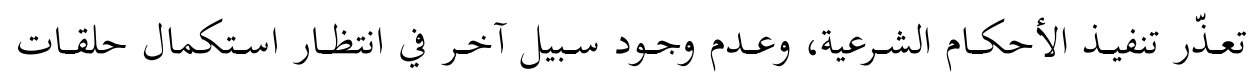

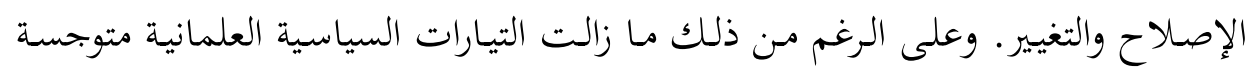

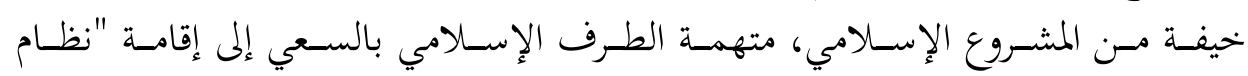
أوتوقراطي" بالطريقة المتدرجة.

ومن تم، فليس من الصحيح أن المنظومة الإسلامية هي كلها مدونة سلوكية وضعية

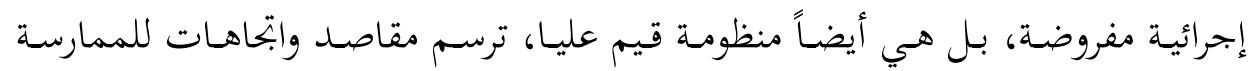

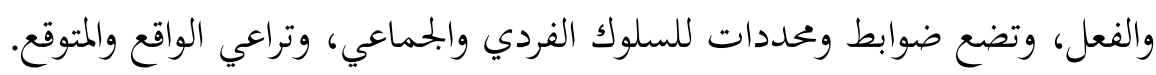

خاتمة:

على الرغم من التطور القانولي في بجال فلسفة القانون واستثماره في التطبيق والتنزيل

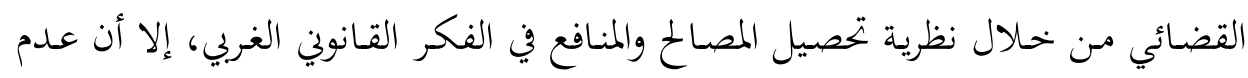

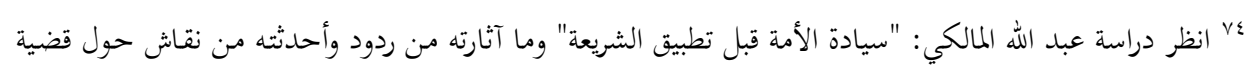

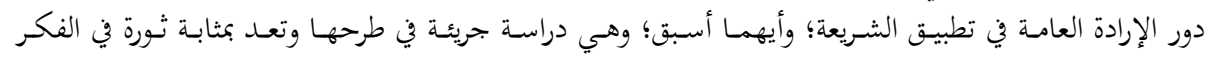

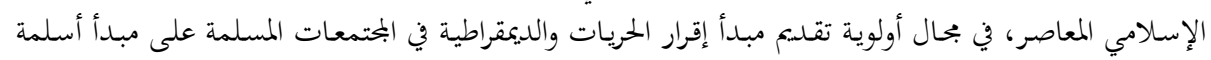

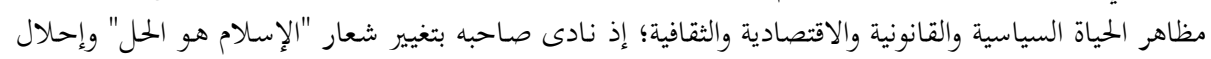

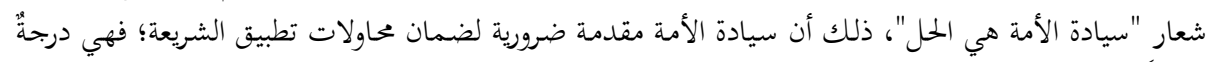

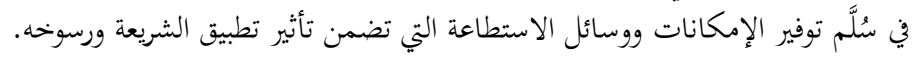


وضوح الغاية الأساسية للتشريع الوضعي، أفقده مصداقيته في معالجـة عدد من القضـايا

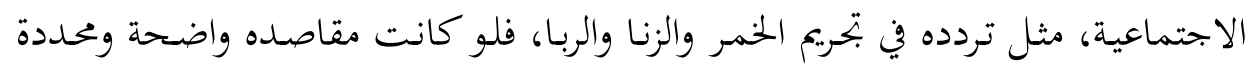

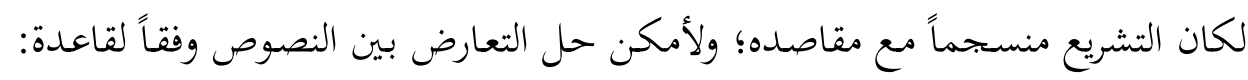

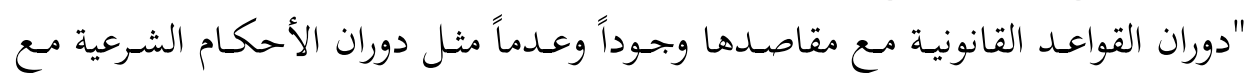

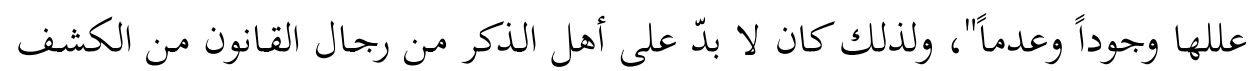

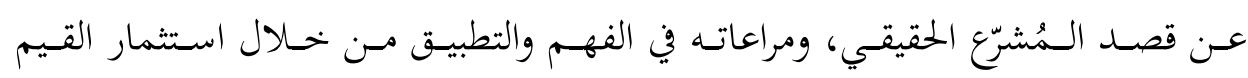
المصلحية لدى فلاسفة القانون.

وبذلك فقد كشفت الدراسة عن الدور الذي يجب أن تتبوَّاه نظرية مقاصد القانون

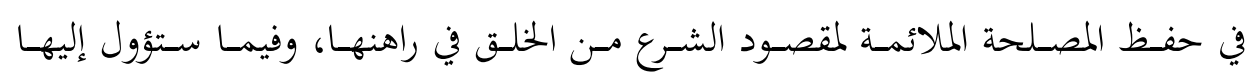
نتائجها، بكيث تكون إرادة الشارع ومقصوده موجهين للنصوص القانونية عند تطبيقها في

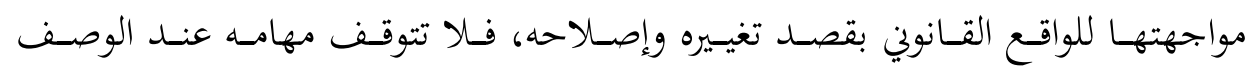

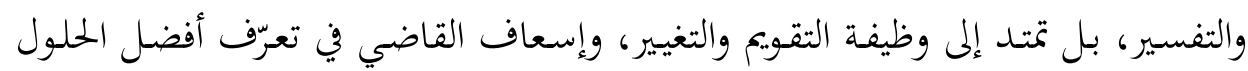

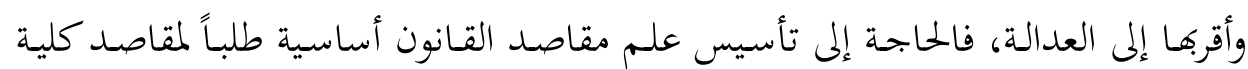

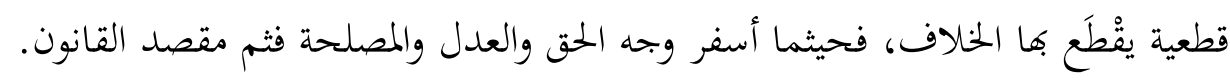
وتوصسي الدراسـة في خاتمتهـا بــدعوة البـاحثين المقاصــيبن إلى الانتقـال بـالبحوث

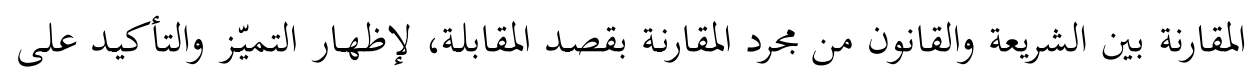

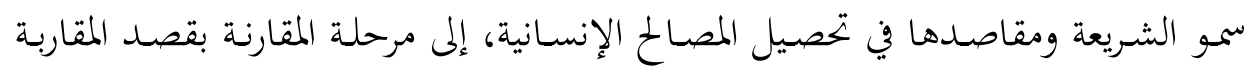

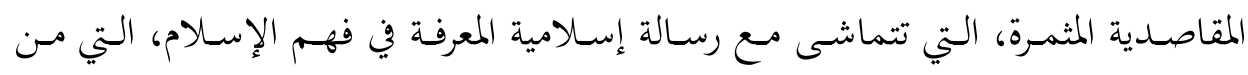

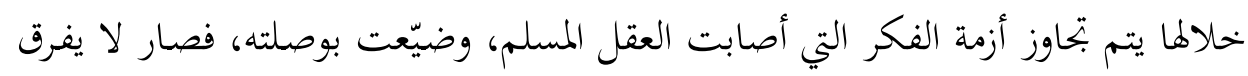

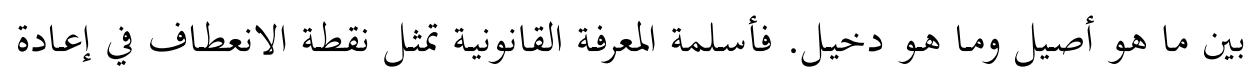

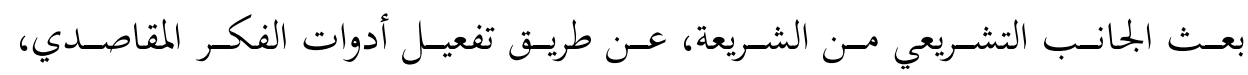

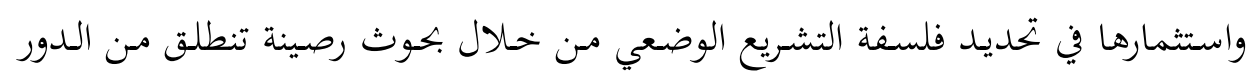

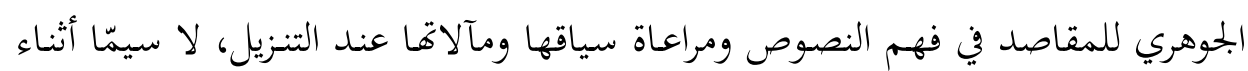

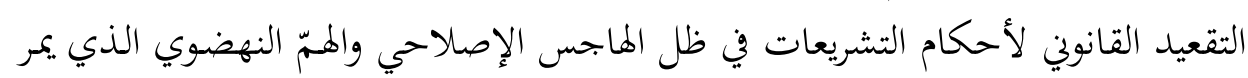

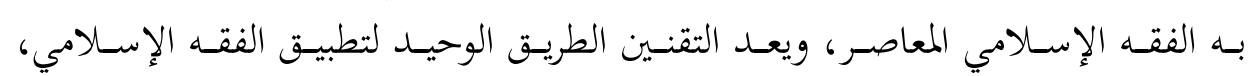

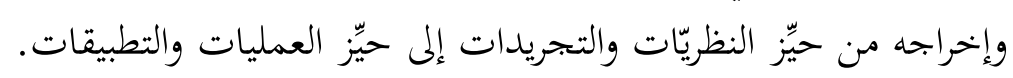

